Prepared in cooperation with the National Park Service

\title{
Sea-Cliff Bedstraw (Galium buxifolium) Patterns and Trends, 2005-14, on Santa Cruz and San Miguel Islands, Channel Islands National Park, California
}

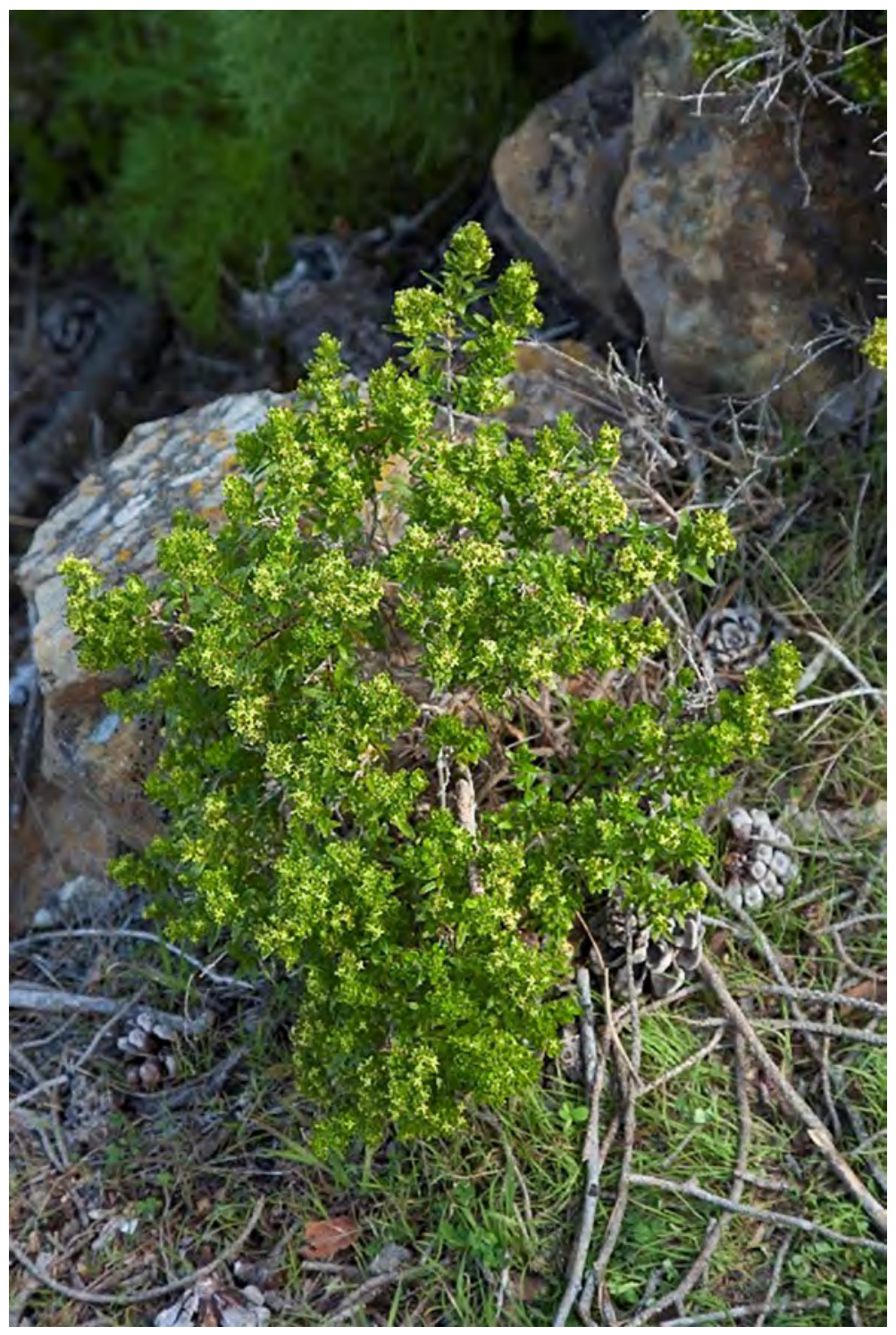

Open-File Report 2019-1054

U.S. Department of the Interior

U.S. Geological Survey 
Cover photograph: Sea-cliff bedstraw (Galium buxifolium) in flower, Pelican Bay, Santa Cruz Island, 2011. Photograph by Udi Gohren, Brooks Institute of Photojournalism. 


\section{Sea-Cliff Bedstraw (Galium buxifolium) Patterns and Trends, 2005-14, on Santa Cruz and San Miguel Islands, Channel Islands National Park, California}

By Kathryn McEachern, Katherine A. Chess, Karen Flagg, and

Kenneth G. Niessen

Prepared in cooperation with the National Park Service

Open-File Report 2019-1054 


\title{
U.S. Department of the Interior \\ DAVID BERNHARDT, Secretary
}

\author{
U.S. Geological Survey \\ James F. Reilly II, Director
}

U.S. Geological Survey, Reston, Virginia: 2019

For more information on the USGS - the Federal source for science about the Earth, its natural and living resources, natural hazards, and the environment-visit https://www.usgs.gov or call 1-888-ASK-USGS.

For an overview of USGS information products, including maps, imagery, and publications,

visit https://store.usgs.gov.

Any use of trade, firm, or product names is for descriptive purposes only and does not imply endorsement by the U.S. Government.

Although this information product, for the most part, is in the public domain, it also may contain copyrighted materials as noted in the text. Permission to reproduce copyrighted items must be secured from the copyright owner.

Suggested citation:

McEachern, K., Chess, K.A., Flagg, K., and Niessen, K.G., 2019, Sea-cliff bedstraw (Galium buxifolium) patterns and trends, 2005-14, on Santa Cruz and San Miguel Islands, Channel Islands National Park, California: U.S. Geological Survey Open-File Report 2019-1054, 23 p., https://doi.org/10.3133/ofr20191054. 


\section{Acknowledgments}

This research was accomplished with funding from the National Park Service Biological Inventories and Natural Resource Protection Programs, U.S. Geological Survey, and National Science Foundation (RUI 0950106). McEachern conducted this work under U.S. Fish and Wildlife Recovery Research Permit for plants of the northern Channel Islands \#TE-044846-4 (renewal). Thanks to The Nature Conservancy for site access, Channel Islands National Park for logistical support, and Channel Islands Restoration and Channel Islands National Park for periwinkle herbicide application. Thanks for field support from many technicians, colleagues, and volunteers, including (in approximate order of appearance) Dieter Wilken, Emily Schulz, Aaron Schmidt, Udi Gohren, Edward Demmond, Allison Gracer, Sarah Chaney, Ken Owen, Kevin Thompson, Dave Chang, Clark Cowan, and Jim Roberts. Dieter Wilken and Dirk Rodriguez provided valuable reviews of this manuscript. 


\section{Contents}

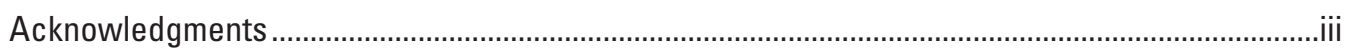

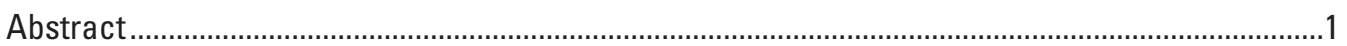

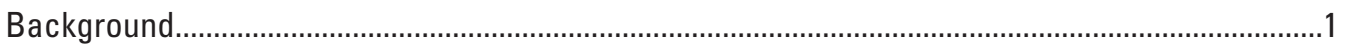

Floral Biology and Seed Ecology of Sea-Cliff Bedstraw (Galium buxifolium) ...................................

Distribution and Abundance on Santa Cruz and San Miguel Islands .............................................6

Updated Maps and Tables of Occurrence on Santa Cruz, Santa Rosa, and San Miguel

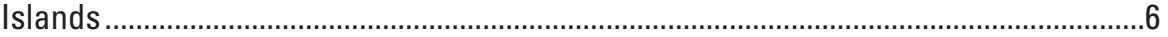

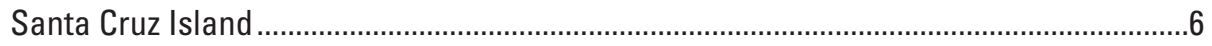

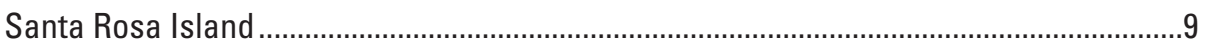

San Miguel Island ...............................................................................................

Life History and Population Structure, 2005-06, at Eagle Canyon, Tinker's Cove, and Cueva

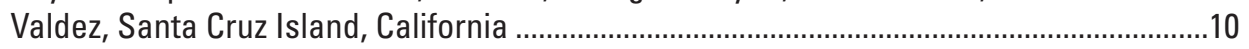

Methods: Life History and Population Structure at Eagle Canyon, Tinker's Cove, and

Cueva Valdez, 2005-06...........................................................................................11

Results and Discussion: Life-History and Population Structure at Eagle Canyon,

Tinker's Cove, and Cueva Valdez, 2005-06 ..............................................................11

Life-History, Population Demography, and Invasive Plant Control at Pelican Bay, 2005-14...........14

Methods: Pelican Bay Demography and Invasive Plant Control............................................14

Results and Discussion: Pelican Bay Demography and Invasive Plant Control ......................15

Sampling and Treatment Timeline ............................................................................15

Population Stage Structure, Recruitment, and Mortality, 2005-14_................................16

Fates of the Original 106 Vegetative and Reproductive Plants Found in 2005-06...........17

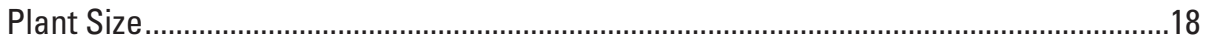

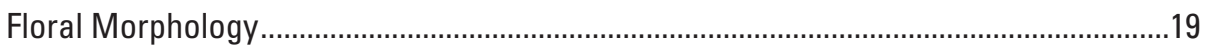

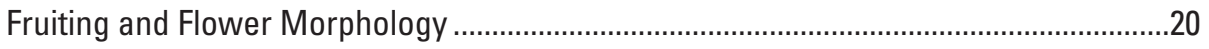

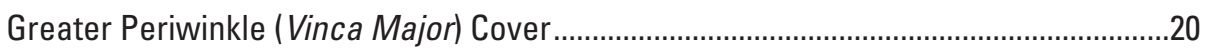

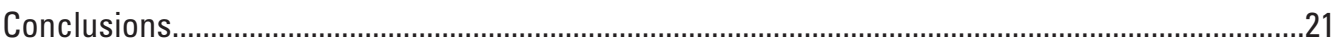

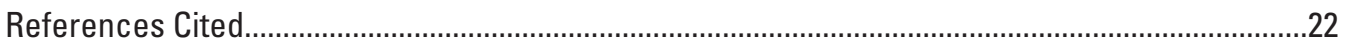

\section{Figures}

Figure 1. Photograph showing sea-cliff bedstraw (Galium buxifolium) habitat, bluff west of Cueva Valdez, Santa Cruz Island, California, 2004

Figure 2. Photograph showing sea-cliff bedstraw (Galium buxifolium) buds and flowers ............3

Figure 3. Photograph showing sea-cliff bedstraw (Galium buxifolium) in fruit, Pelican Bay, Santa Cruz Island, California

Figure 4. Map showing sea-cliff bedstraw (Galium buxifolium) distribution on Santa Cruz Island, California

Figure 5. Map showing sea-cliff bedstraw (Galium buxifolium) distribution 1930-98 on San Miguel Island, California.

Figure 6. Graph showing numbers of sea-cliff bedstraw (Galium buxifolium) plants present across life-history stage in samples at Eagle Canyon, Tinker's Cove, and Cueva Valdez on Santa Cruz Island, California, 2005-06.

Figure 7. Graph showing percent of floral types represented among sea-cliff bedstraw (Galium buxifolium) at Eagle Canyon, Tinker's Cove, and Cueva Valdez on Santa Cruz Island, California, 2005-06. 
Figure 8. Photograph showing sea-cliff bedstraw (Galium buxifolium) population at Pelican Bay, 2008.

Figure 9. Photograph showing hand-application of herbicide to greater periwinkle (Vinca major) within a population of sea-cliff bedstraw (Galium buxifolium) at Pelican Bay, Santa Cruz Island, California, 2009.

Figure 10. Graph showing numbers of sea-cliff bedstraw (Galium buxifolium) across lifehistory stages at Pelican Bay on Santa Cruz Island, California, 2005-14..

Figure 11. Graph showing stage structure and fates of the original non-seedling sea-cliff bedstraw (Galium buxifolium) plants tagged in 2005 and 2006 in the Pelican Bay plot on Santa Cruz Island, California, tracked individually 2005-14

\section{Tables}

Table 1. Sea-cliff bedstraw (Galium buxifolium) seed germination trials, 2005-06.

Table 2. Mass (grams) of fresh fruits and nutlets (seeds) from collections from 28 plants at 3 Santa Cruz Island, California, sea-cliff bedstraw (Galium buxifolium) populations, August 2006

Table 3. Average fruit mass (grams) for 11 plants of known floral morphology type collected August 2006 at 3 Santa Cruz Island, California, sea-cliff bedstraw (Galium buxifolium) populations

Table 4. Sea-cliff bedstraw (Galium buxifolium) survey results from Santa Cruz Island, California, 2004-06: approximate area occupied and total plants in populations

Table 5. Numbers of sea-cliff bedstraw (Galium buxifolium) plants estimated from historic records to be present at each site, 1886-1998, San Miguel Island, California

Table 6. Numbers of sea-cliff bedstraw (Galium buxifolium) sampled at Eagle Canyon, Tinker's Cove, and Cueva Valdez on Santa Cruz Island, California, 2005-06 ....

Table 7. Percent of life-history stages present in sea-cliff bedstraw (Galium buxifolium) samples at Eagle Canyon, Tinker's Cove, and Cueva Valdez on Santa Cruz Island, California, 2005-06

Table 8. Mean plant sizes of sea-cliff bedstraw (Galium buxifolium) plants at Eagle Canyon, Tinker's Cove, and Cueva Valdez on Santa Cruz Island, California, 2005-06.....12

Table 9. Sea-cliff bedstraw (Galium buxifolium) sample dates at Eagle Canyon, Tinker's Cove, and Cueva Valdez on Santa Cruz Island, California, 2005-06.....

Table 10. Sampling and treatment dates at the Pelican Bay sea-cliff bedstraw (Galium buxifolium) population, 2005-14, Santa Cruz Island, California.

Table 11. Total live plants present in the Pelican Bay sea-cliff bedstraw (Galium buxifolium) plot, 2005-14, Santa Cruz Island, California

Table 12. Mean plant size of vegetative and reproductive sea-cliff bedstraw (Galium buxifolium) sampled at Pelican Bay on Santa Cruz Island, California, 2005-14.

Table 13. Percent of floral types represented among reproductive sea-cliff bedstraw (Galium buxifolium) individuals at Pelican Bay, Santa Cruz Island, California, 2005-14

Table 14. Flower morphology recorded in 2014 for 41 sea-cliff bedstraw (Galium buxifolium) plants that were developing fruits at Pelican Bay, Santa Cruz Island, California 


\section{Conversion Factors}

U.S. customary units to International System of Units

\begin{tabular}{lcl}
\hline \multicolumn{1}{c}{ Multiply } & By & \multicolumn{1}{c}{ To obtain } \\
\hline & Length & \\
\hline inch (in.) & 2.54 & centimeter $(\mathrm{cm})$ \\
inch (in.) & 25.4 & millimeter $(\mathrm{mm})$ \\
mile (mi) & 1.609 & kilometer $(\mathrm{km})$ \\
\hline
\end{tabular}

International System of Units to U.S. customary units

\begin{tabular}{lcl}
\hline \multicolumn{1}{c}{ Multiply } & By & \multicolumn{1}{c}{ To obtain } \\
\hline & Length & \\
\hline centimeter $(\mathrm{cm})$ & 0.3937 & inch (in.) \\
millimeter $(\mathrm{mm})$ & 0.03937 & inch (in.) \\
meter $(\mathrm{m})$ & 3.281 & foot (ft) \\
kilometer $(\mathrm{km})$ & 0.6214 & mile (mi) \\
kilometer $(\mathrm{km})$ & 0.5400 & mile, nautical $(\mathrm{nmi})$ \\
meter $(\mathrm{m})$ & 1.094 & yard $(\mathrm{yd})$ \\
\hline & Area & \\
\hline square meter $\left(\mathrm{m}^{2}\right)$ & 0.0002471 & acre \\
square centimeter $\left(\mathrm{cm}^{2}\right)$ & 0.001076 & square foot $\left(\mathrm{ft}^{2}\right)$ \\
square meter $\left(\mathrm{m}^{2}\right)$ & 10.76 & square foot $\left(\mathrm{ft}^{2}\right)$ \\
square centimeter $\left(\mathrm{cm}^{2}\right)$ & 0.1550 & square inch $\left(\mathrm{ft}^{2}\right)$ \\
\hline & Mass & \\
\hline gram $(\mathrm{g})$ & 0.03527 & ounce, avoirdupois $(\mathrm{oz})$ \\
\hline
\end{tabular}

\section{Abbreviations}

USFWS U.S. Fish and Wildlife Service

USGS U.S. Geological Survey 


\title{
Sea-Cliff Bedstraw (Galium buxifolium) Patterns and Trends, 2005-14, on Santa Cruz and San Miguel Islands, Channel Islands National Park, California
}

\author{
By Kathryn McEachern'1, Katherine A. Chess', Karen Flagg'1, and Kenneth G. Niessen¹
}

\begin{abstract}
Sea-cliff bedstraw (Galium buxifolium [Rubiaceae]) is a delicate dioecious subshrub endemic to Santa Cruz and San Miguel Islands, in the northern California Channel Islands. It was listed as endangered in 1997 under the Federal Endangered Species Act, threatened by soil loss, habitat alteration, and herbivory from more than a century of ranching land use. At the time of listing, there were eight populations known from Santa Cruz Island and two from San Miguel Island, restricted to shaded, northfacing volcanic ocean bluffs. The recovery plan included criteria to be considered for delisting such as stabilizing or increasing populations on both islands and recovery actions such as searching for more populations, seed banking, researching seed germination and life history, and reversing factors causing decline.

We began studying sea-cliff bedstraw on Santa Cruz Island in the early 2000s to better understand factors related to decline. We surveyed historic populations and searched for new occurrences 2004-06, researched population size-class structure and floral biology 2005-06 at three sites, and tracked demography 2005-14 while treating the invasive periwinkle (Vinca major) with herbicide at a fourth site. We collected seeds for germination studies and long-term seed banking from all four study sites.

The historically known Santa Cruz Island sites were still extant on the sea-cliffs, and we located 14 occurrences not documented at the time of listing. Sea-cliff bedstraw floral morphology appears evenly balanced between mainly pistillate and staminate plants at the study sites, with other floral types present as well, in the populations we sampled. Seed germination trials showed about a 40 percent germination rate from fresh imbibed seeds. Life-history stage structure 2005-06 varied from purely reproductive plants at one site to nearly equal representation of vegetative and reproductive plants at a second site, with seedlings also present at the remaining two sites.

Demographic study of tagged plants at the long-term study plot 2005-14 showed an episodic pattern of high recruitment with low mortality once plants became established beyond the first summer dormant season. A flush of seedlings was seen after periwinkle reduction, indicating that the periwinkle may have been repressing seedling establishment. About 93 percent of the already-established plants tagged in 2005 and 2006 were still present 10 years later in 2014. Findings indicate that sea-cliff bedstraw individuals are long-lived and once established have good survival rates. Taken together, these results imply that population growth is driven more by germination and recruitment into the mature population than by mortality of established plants, at least since feral animal eradication from Santa Cruz Island. Therefore, conservation actions might be best focused on nurturing safe sites for seed germination and seedling survival.
\end{abstract}

\section{Background}

Sea-cliff bedstraw (Galium buxifolium [Rubiaceae]) is a delicate subshrub endemic to Santa Cruz and San Miguel Islands, in the northern California Channel Islands. It was listed as endangered in 1997 under the Federal Endangered Species Act (U.S. Fish and Wildlife Service, 1997), threatened by soil loss, habitat alteration, and herbivory from more than a century of ranching land use. At the time of listing in 1997, there were eight populations known from Santa Cruz Island and two from San Miguel Island (Hochberg and others, 1979; U.S. Fish and Wildlife Service, 1997), restricted to shaded, north-facing volcanic ocean bluffs (fig. 1). At that time, 2 of the 8 Santa Cruz Island populations were known to have less than 50 individuals each, and the remaining 6 had fewer than 6 plants each. In 1998, the 2 San Miguel Island populations were found to have 121 and nearly 300 plants each (U.S. Fish and Wildlife Service, 2000). Recovery plan (U.S. Fish and Wildlife Service, 2000) criteria for delisting include stabilizing or increasing populations on both islands and discovering or establishing at least five additional populations on each island; recovery actions include seed banking, researching seed germination and life history, and determining and reversing factors causing decline.

${ }^{1}$ U.S. Geological Survey 


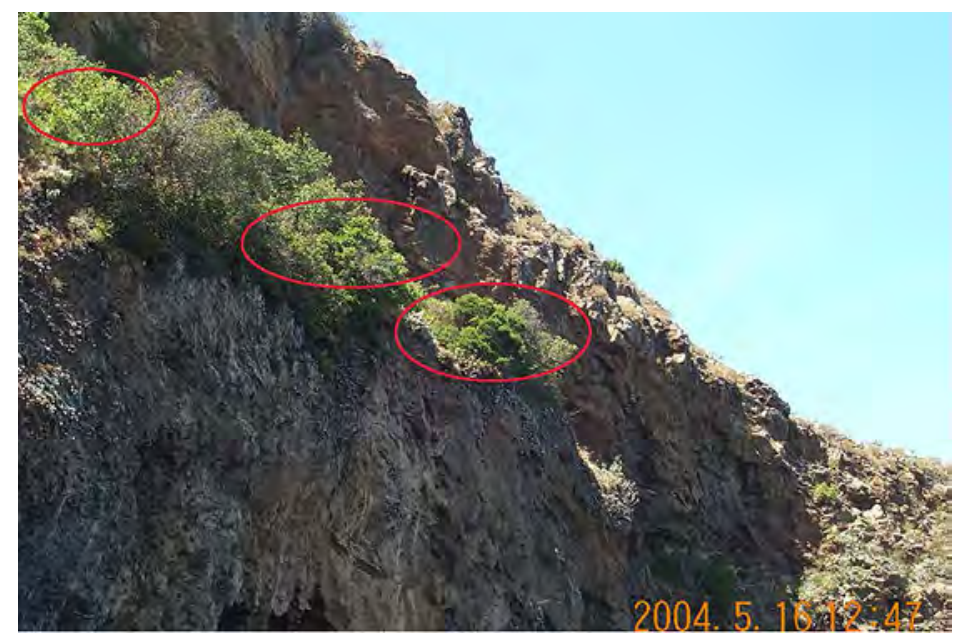

Figure 1. Sea-cliff bedstraw (Galium buxifolium) habitat, bluff west of Cueva Valdez, Santa Cruz Island, California, 2004. Oval encompasses sea-cliff bedstraw habitat. Photo: M. Barmann, U.S. Geological Survey.

One of the greatest threats to the native island flora and fauna, including the sea-cliff bedstraw, was the continued presence of feral ranch animals. The last feral ranch animals were removed from San Miguel Island in 1976 (McEachern and others, 2016). The Nature Conservancy successfully removed sheep from about 90 percent of Santa Cruz Island in the late 1980s. They joined with Channel Islands National Park to remove sheep from the remaining 10 percent of the island in 1999-2001 (McEachern and others, 2016), and together they eradicated feral pigs from the entire island in 2003-06 (Morrison, 2007). Although this was arguably the single best conservation action that could be taken for rare plant recovery (McEachern and Wilken, 2011), it was not clear at the time of the most recent Galium buxifolium 5-year review (U.S. Fish and Wildlife Service, 2009) whether the sea-cliff bedstraw was on a recovery trajectory because of the lingering effects of habitat damage, presence of non-natives, and lack of clear evidence of population expansion.

We began studying sea-cliff bedstraw in the early 2000s and have developed a spatial database of current and historic occurrences. In 2005-07, we searched for about 27 known and potential Santa Cruz Island localities on foot and by kayak, sampled population size-class structure and recorded floral biology at 4 Santa Cruz Island sites, and collected seeds for germination studies and long-term seed banking (McEachern and others, 2010a). Seed germination studies were conducted with colleagues at the Santa Barbara Botanic Garden in 2005-06 (Dieter Wilken, Santa Barbara Botanic Garden, unpub. data, 2006). In 2007, a study plan (McEachern and Chess, 2007) and Intra-service biological opinion (U.S. Fish and Wildlife Service, 2007) were developed for control of the invasive periwinkle (Vinca major) at the Pelican Bay site, one of the largest populations on Santa Cruz Island. Periwinkle control was done by consultant Channel Islands Restoration, using herbicide and hand-pulling from 2008 to 2013 (McEachern and others, 2010b). Sea-cliff bedstraw demography and periwinkle cover data were collected at the Pelican Bay site intermittently 2005-14, documenting periwinkle control efficacy and effects on bedstraw population trends. On San Miguel Island, our studies have been limited to collecting and archiving occasional observations from ourselves and colleagues, made by happenstance during the pursuit of other island work. This report summarizes information from past reports, provides updates with ongoing research results, and is associated with an accompanying data release (McEachern and others, 2019, https://doi.org/10.5066/P94J36GC). This research was accomplished with funding from the National Park Service Biological Inventories and Natural Resource Protection Programs, U.S. Geological Survey, and National Science Foundation (RUI 0950106). 


\section{Floral Biology and Seed Ecology of Sea-Cliff Bedstraw (Galium buxifolium)}

Galium buxifolium has been traditionally placed in section Lophogalium (Schumann, 1897; Dempster, 1973), which is characterized as being polygamous or dioecious with dry fruits with long straight hairs. However, more recent genetic analysis by Soza and Olmstead (2010) has shown that Lophogalium is not monophyletic, with members falling into five of nine welldefined clades, and that the traditional sections are unsupported.

In her review of many herbarium specimens, Dempster (1973) found sea-cliff bedstraw individuals varying across a range from fully pistillate plants through individuals with a variety of combinations of pistillate and staminate floral morphologies on one plant, to purely staminate plants (fig. 2). She found that most individuals can be classified as predominately pistillate or predominately staminate, presumably leading to effects on fruit and seed production: pistillate flowers tended to have larger ovaries and were less likely to be sterile than staminate flowers, and predominately pistillate plants had more pistillate flowers than predominately staminate plants. Greene (1886) described the floral biology of the newly found G. buxifolium as "unknown," and it has since been described as "usually dioecious" (Junak and others, 1995) and currently as "bisexual or unisexual" (= polygamous, Soza, 2012). Dempster (1973) noted that fruits develop as pairs of seed-bearing nutlets varying in presence and size according to floral type. She indicated that the polygamous Galiums recruit from seed, lacking the capacity for vegetative reproduction, even though they have the capacity to sprout numerous stems from the caudex at the base of the stem.

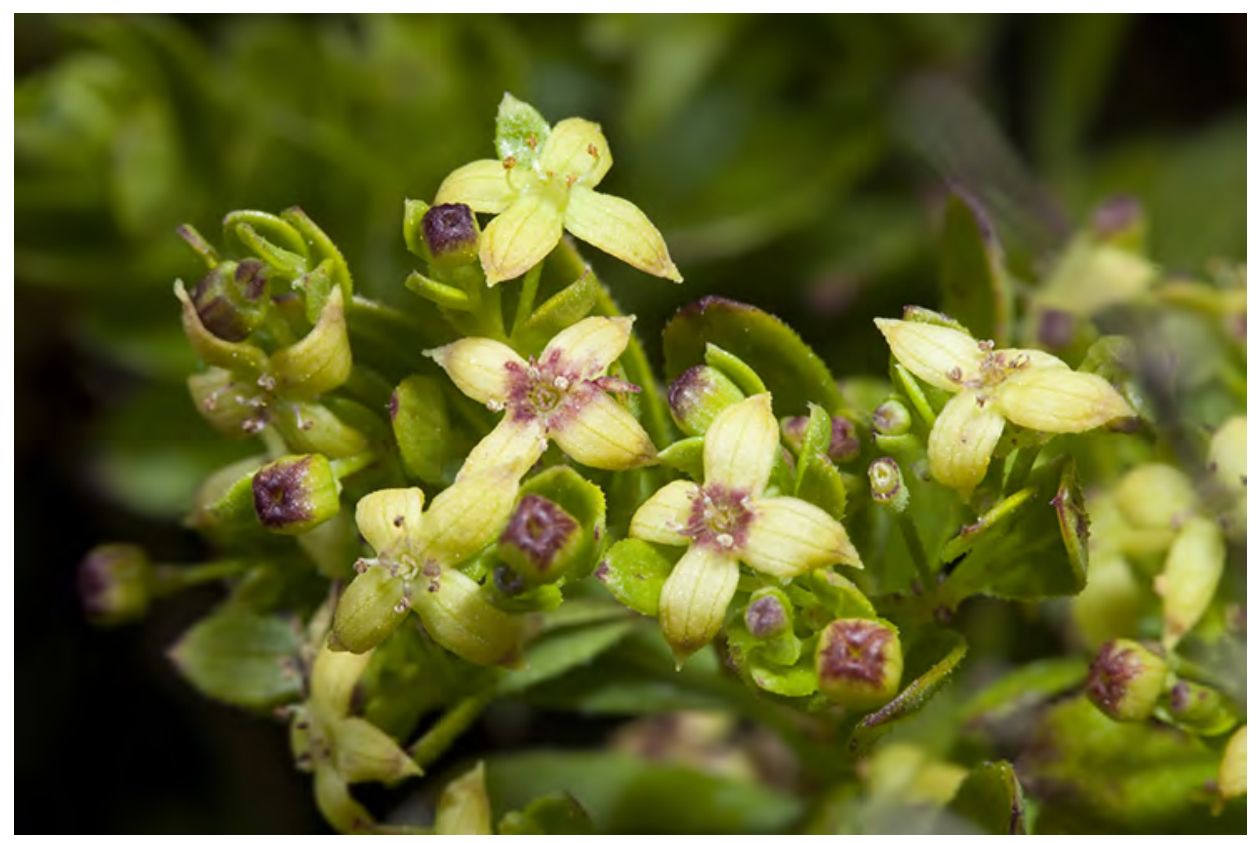

Figure 2. Sea-cliff bedstraw (Galium buxifolium) buds and flowers. Photo: Udi Gohren, 2012, Brooks Institute of Photojournalism, Ventura, California.

Little was known about the floral biology of the islands' sea-cliff bedstraw populations. Particularly important for conservation, sea cliff bedstraw was known in 1997 as 10 small and isolated populations scattered on sea cliff faces on Santa Cruz and San Miguel Islands (U.S. Fish and Wildlife Service, 1997, 2000). If any of the populations were found to be mainly staminate, rarely producing fertile fruits, this would place the population at greater risk of extirpation from failure to recruit new individuals. Therefore, we initiated population-level studies in 2005 , with the intention of determining floral types within populations, among other attributes (see later sections for more detail).

We also collected seed-bearing nutlets and deposited them with Dieter Wilken at the Santa Barbara Botanic Garden for seed banking and seed germination trials. Nutlets were collected June-August 2005 and August-September 2006 from Eagle Canyon, Tinker's Cove, Pelican Bay, and Cueva Valdez study populations, with numbers collected ranging from 25 to an estimated 2,029-2,768 across the sites and years, depending on seed set and availability (McEachern and others, 2010a). 
Wilken used a subset of the 2005 collections in germination trials (Dieter Wilken, Santa Barbara Botanic Garden, unpub. data, 2006). Field-collected nutlets were imbibed with water for 24 hours and then planted in standard Santa Barbara Botanic Garden growing mix (sand: peat moss) in 4-inch pots and watered as needed. Pots were held in an outdoor screen house at ambient temperatures between November 2005 and February 2006. Table 1 shows results. The overall germination rate was 40 percent (64 seedlings from 160 seeds planted). Emergent dates were recorded once it was observed that not all seeds were germinating at the same time. Wilken noted that seedling emergence appears to be protracted, probably for several reasons, including seed biology and diurnal temperatures (which were unseasonably cold for several months during the winter of 200506). Because seeds were not "culled" by weight or size, it is also possible that low germination rates and protracted germination may also be the result of variation in seed "quality." Requirements for "breaking" dormancy remain unknown.

Table 1. Sea-cliff bedstraw (Galium buxifolium) seed germination trials, 2005-06. Source: Dieter Wilken, Santa Barbara Botanic Garden, Santa Barbara, California, unpub. data, 2006.

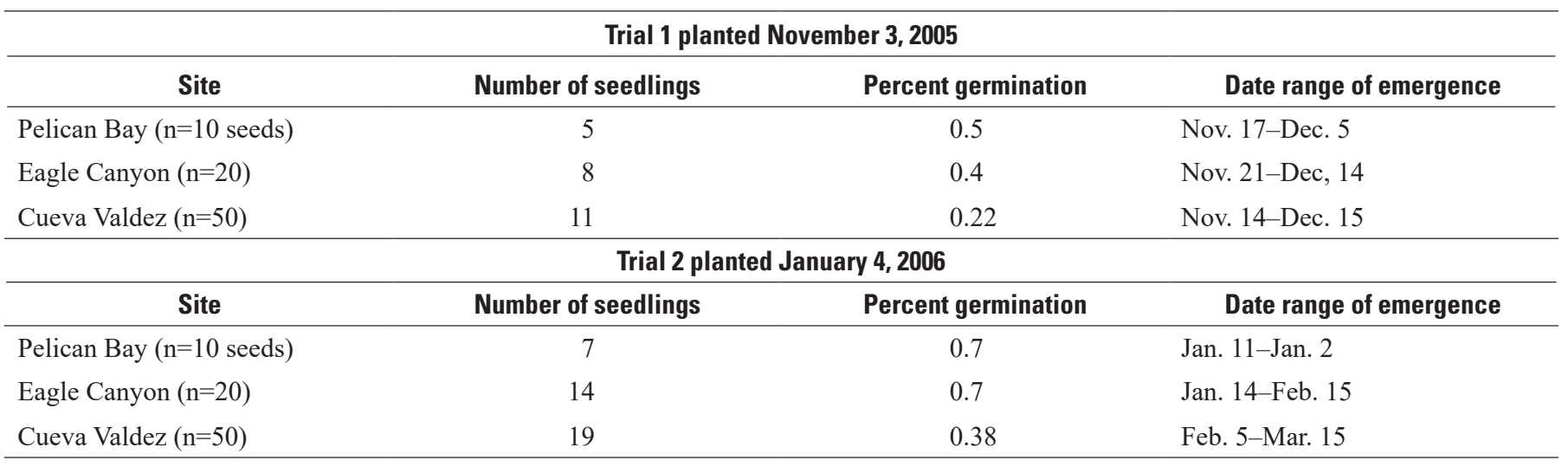

From August 11-29, 2006, we collected and weighed fruits and nutlets (fig. 3) from a total of 28 plants at the Eagle Canyon (3 plants), Tinker's Cove (5 plants), and Pelican Bay (20 plants) sites; fruits were already fallen at that time from the plants at the Cueva Valdez site. Fruit and seed set varied across the plants within each population, likely in response to some combination of sun, heat, and wind. When the fruits were ripe, they readily detached from the plant, usually separating in half. Interestingly, many plants produced a mixed fruit set with some fully formed, well-developed fruit and others that had started to grow but failed to develop. On some plants the entire fruit set was stalled at a very early stage, and maturation did not occur. Other plants had an excellent fruit set with most fruits fully formed and both nutlets equally developed and ripening well. These observations are consistent with Dempster's 1973 findings that ovary and fruit size varied across plants, related to floral morphology. 


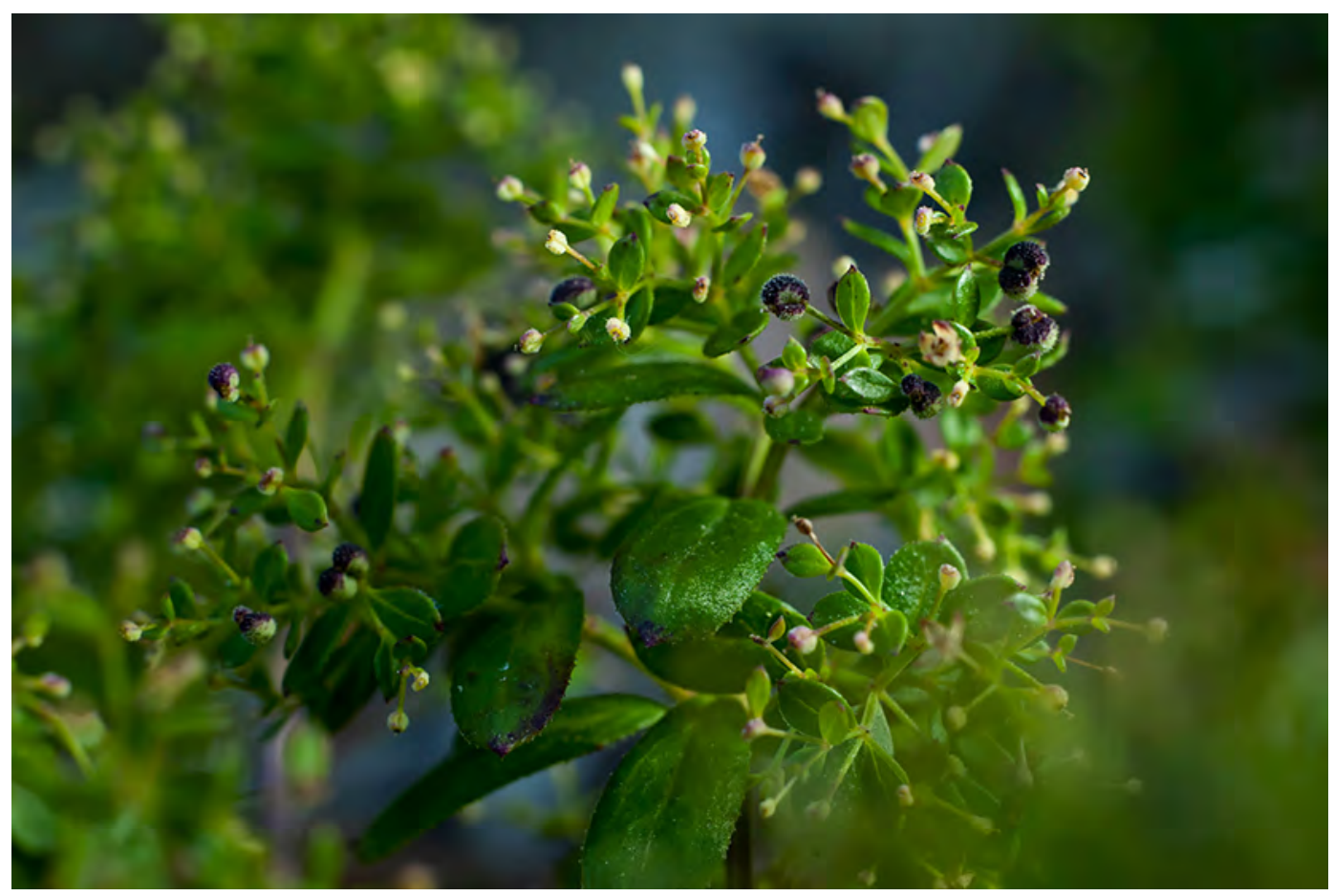

Figure 3. Sea-cliff bedstraw (Galium buxifolium) in fruit, Pelican Bay, Santa Cruz Island, California. Photo: Aaron Schmidt, 2011, Brooks Institute of Photojournalism, Ventura, California.

Table 2 shows the average mass (grams) of the fresh fruits and their nutlets from the August 2006 collections. There was no systematically varying fruit morphology that allowed us to identify the nutlets by orientation or position within the fruit. Overall, 168 intact fruits were retrieved and weighed; the nutlets in 16 of those fruits were so strongly fused together that they could not be separated into their two nutlets. An additional 34 single-nutlets were collected from pedicels still attached to the plant, where the second nutlet had already separated and fallen. Where the two nutlets differed in mass, the one we called nutlet 1 is always the heavier of the two. Table 3 presents fruit mass for nine plants within this collection, where the floral morphology of the mother plant was known from previous sampling that same year. Fruit and nutlet mass were highly variable, ranging across several orders of magnitude for the collection. Predominantly pistillate, staminate (for example, with reduced pistil), and perfect flowers produced fruits. There were no apparent differences among floral types, albeit from a small sample size. It appears that seed production at the study sites could be affected by both floral morphology and environment, but more work would need to be done to determine this with a high degree of statistical adequacy.

Table 2. Mass (grams) of fresh fruits and nutlets (seeds) from collections from 28 plants at 3 Santa Cruz Island, California, sea-cliff bedstraw (Galium buxifolium) populations, August 2006.

\begin{tabular}{lccc}
\hline & $\begin{array}{c}\text { Fruit mass } \\
\text { (gram) }\end{array}$ & $\begin{array}{c}\text { Nutlet 1 mass } \\
\text { (gram) }^{\mathbf{1}}\end{array}$ & $\begin{array}{c}\text { Nutlet 2 mass } \\
\text { (gram) }\end{array}$ \\
\hline Mean & 0.0015 & 0.0010 & 0.0006 \\
Standard deviation & 0.0005 & 0.0003 & 0.0004 \\
Minimum & 0.0001 & 0.0001 & 0.0001 \\
Maximum & 0.0029 & 0.0018 & 0.0017 \\
Number of Fruits/Nutlets & 168 & 181 & 147 \\
\hline
\end{tabular}

${ }^{1}$ Where only one nutlet was retrieved, that weight is included as nutlet 1 . 
Table 3. Average fruit mass (grams) for 11 plants of known floral morphology type collected August 2006 at 3 Santa Cruz Island, California, sea-cliff bedstraw (Galium buxifolium) populations.

\begin{tabular}{lccc}
\hline & $\begin{array}{c}\text { Predominately pistillate } \\
(\mathbf{n}=\mathbf{4})\end{array}$ & $\begin{array}{c}\text { Predominately staminate } \\
(\mathbf{n}=\mathbf{5})\end{array}$ & $\begin{array}{c}\text { Predominately perfect } \\
(\mathbf{n}=\mathbf{2})\end{array}$ \\
\hline Mean & 0.0017 & 0.0015 & 0.0013 \\
Standard deviation & 0.0003 & 0.0005 & 0.0007 \\
Minimum & 0.0013 & 0.0008 & 0.0008 \\
Maximum & 0.0023 & 0.0028 & 0.0018 \\
\hline
\end{tabular}

\section{Distribution and Abundance on Santa Cruz and San Miguel Islands}

\section{Updated Maps and Tables of Occurrence on Santa Cruz, Santa Rosa, and San Miguel Islands}

In 2004, we developed a spatial database and search strategy for relocating historic collection locations on Santa Cruz Island (McEachern and others, 2010a), at the same time compiling historic information on localities on San Miguel and Santa Rosa Islands. Our information was derived from herbarium label information (not yet available in online databases) from local and regional herbaria, field notes, and the memories of local botanists. We found records with good locational information for 11 populations. We searched on foot for these localities during 2005-07 and documented them by estimating numbers of individuals and general occurrence extent. Because these populations were on cliff faces, they were not totally visible to us, so our records confirm a continued presence, provide an estimate of plant numbers, and note current extent. Ten of the 11 historic populations that we could relocate with some certainty were still present; the exception is an inland site near Buena Vista on Santa Cruz Island where repeated searches failed to find plants. In addition, there were two historic occurrences noted without collections and clear locational information at both Fry's Harbor and Forney's Cove that were not surveyed. We also searched likely cliff-face habitats along the north shore of Santa Cruz Island and found an additional 14 occurrences.

In general, we have no new records for sea-cliff bedstraw from Santa Cruz, Santa Rosa, and San Miguel Islands from between 2006 and 2019. This is largely because the spatial database has not been active, and more recent records are not yet consolidated in an easily accessible format. However, additional herbarium label information after 2006 for Galium buxifolium on Santa Cruz and San Miguel Islands will likely not substantially change overall numbers or patterns of distribution.

\section{Santa Cruz Island}

Figure 4 shows sea-cliff bedstraw localities on Santa Cruz Island as of 2006 (McEachern and others, 2010a), and table 4 shows numbers of plants estimated to be present at each site (McEachern and others, 2010a). No new occurrences or sites have been added since 2006. In 2006, we knew of 13 localities, and we found a total of 14 more sites. The recovery plan (U.S. Fish and Wildlife Service, 2000) cites eight extant populations. In 2006, we mapped occurrences as distinct from one another whenever they were 400 meters (one-quarter mile) from the next nearest occurrence, following conventional mapping procedures of the California Native Plant Society (2001). It is possible that our 2006 mapping was more fine scale than older surveys (for example, Hochberg and others, 1979); thus, some of our occurrences might represent a combination of one or more of the sites as counted in the listing and recovery documents (U.S. Fish and Wildlife Service, 1997, 2000). Recent images collected in 2015 (Morgan Ball and others, Wildlands Conservation Science, unpub. data) apparently show spread beyond some historical boundaries of occurrences, and no new occurrences, but we have not seen the data. The two inland locations (sites 8 and 13) have been checked for plants, and none were found, but these searches are poorly documented. In general, locations of sea-cliff bedstraw on Santa Cruz Island are well known, and the trajectories of the populations still need to be assessed. 


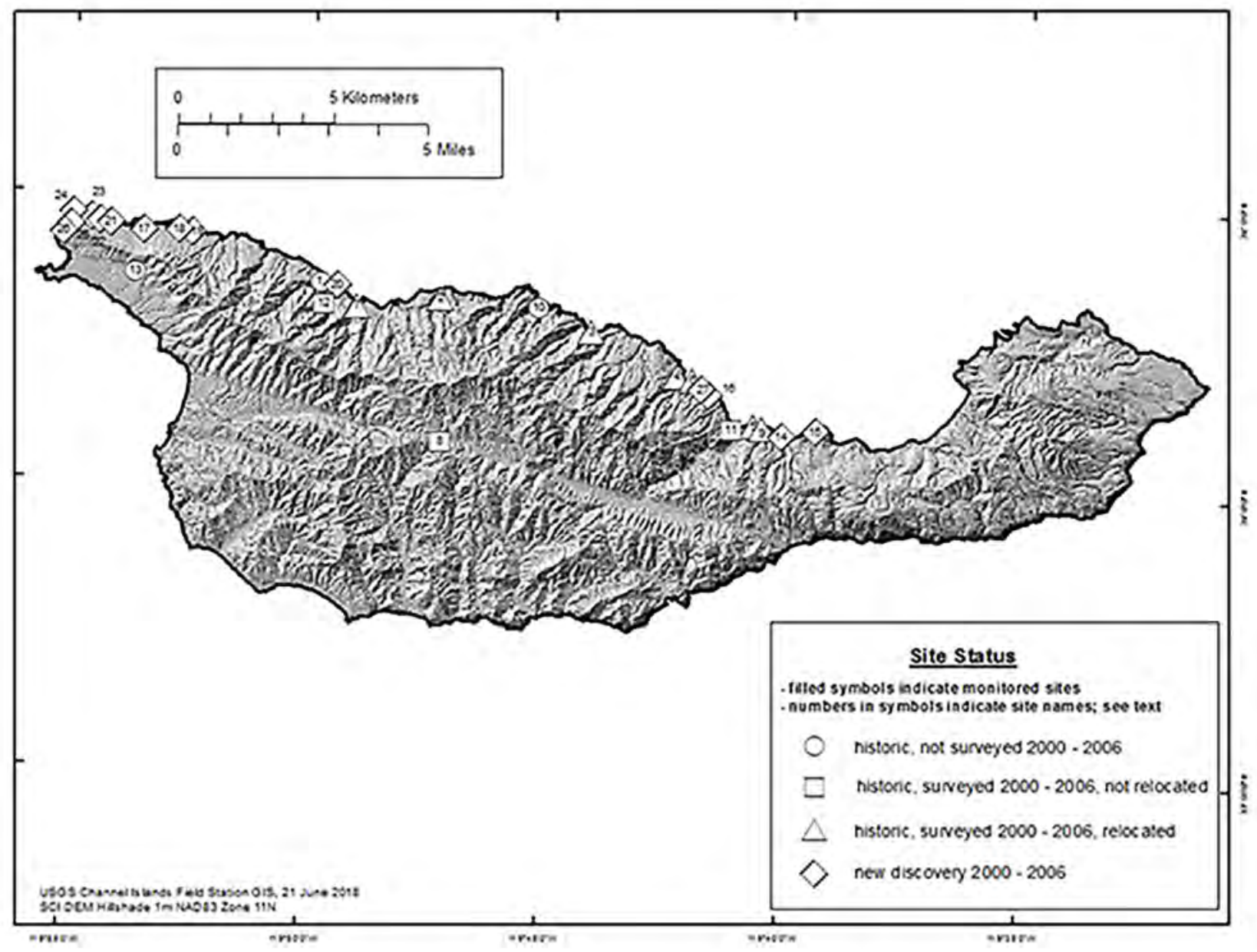

Figure 4. Sea-cliff bedstraw (Galium buxifolium) distribution on Santa Cruz Island, California (adapted from McEachern and others, 2010a, appendix A, fig. A-4). Place names are according to Junak and others, 1995. 
Table 4. Sea-cliff bedstraw (Galium buxifolium) survey results from Santa Cruz Island, California, 2004-06: approximate area occupied and total plants in populations. From McEachern and others, 2010a.

$[\mathrm{km}$, kilometer; m, meter; m², square meter; E, east; N, north; NW, northwest; W, west; +, may be more than the number given; , about; m/dd/yyyy, month, day, year]

\begin{tabular}{|c|c|c|c|c|c|c|}
\hline Site \# & Date & Site name & $\begin{array}{c}\text { Historical area } \\
\left(\mathbf{m}^{2}\right)\end{array}$ & 2004 \# plants & 2005 \# plants & 2006 \# plants \\
\hline 1 & Not surveyed & Hazard's Canyon & & Not surveyed & Not surveyed & Not surveyed \\
\hline 3 & $5 / 5 / 2006$ & Platt's Harbor-Dick's Cove & 400 & & & $50-150$ \\
\hline 4 & $4 / 28 / 2004$ & Pelican Bay ${ }^{1,2}$ & 700 & Plants present & 140 & Plants present \\
\hline 7 & $5 / 16 / 2004$ & Cueva Valdez ${ }^{2,3}$ & 1,660 & 91 & Plants present & Plants present \\
\hline 8 & $5 / 10 / 2004$ & Buena Vista & Not surveyed & $\begin{array}{l}\text { Surveyed, no plants } \\
\text { found }\end{array}$ & Not surveyed & Not surveyed \\
\hline 9 & $4 / 29 / 2004$ & Eagle Canyon $^{2}$ & 8,125 & 175 & Plants present & Plants present \\
\hline 12 & $4 / 21 / 2006$ & $\sim 1 \mathrm{~km} \mathrm{~W}$ of Cueva Valdez beach & Not surveyed & Not surveyed & Not surveyed & $\begin{array}{c}\text { Surveyed, } \\
\text { no plants found }\end{array}$ \\
\hline 13 & Not surveyed & East of Forney's Cove & Not surveyed & Not surveyed & Not surveyed & Not surveyed \\
\hline \multicolumn{7}{|c|}{ New area $\left(\mathrm{m}^{2}\right)$} \\
\hline 14 & $5 / 26 / 2004$ & Canada del Agua ${ }^{4}$ & 4,825 & 147 & Not surveyed & Not surveyed \\
\hline 15 & $5 / 26 / 2004$ & $0.8 \mathrm{~km}$ E of Canada del Agua & 164 & 25 & Not surveyed & Not surveyed \\
\hline 16 & $3 / 26 / 2005$ & Marine Gardens & 1 & Not surveyed & 1 & Not surveyed \\
\hline 17 & $6 / 19 / 2005$ & Del Mar Cove (West End Flats) $^{-}$ & 25 & Not surveyed & $54+$ & Not surveyed \\
\hline 18 & $6 / 19 / 2005$ & $1.15 \mathrm{~km} \mathrm{E}$ of Del Mar Cove ${ }^{5}$ & 1 & Not surveyed & $51+$ & Not surveyed \\
\hline 25 & $5 / 29 / 2006$ & West End, $\mathrm{N}$ of ridge crest & Not surveyed & & Not surveyed & 3 \\
\hline 26 & $5 / 29 / 2006$ & West End, S of ridge crest & Not surveyed & & Not surveyed & $15+$ \\
\hline 27 & $7 / 23 / 2006$ & Marine Gardens, West (W) & Not surveyed & & Not surveyed & $20+$ \\
\hline
\end{tabular}

${ }^{1}$ This site consists of two historical sites located within $130 \mathrm{~m}$ of each other: (1) Pelican, above and east of landing; (2) Pelican, west of landing.

${ }^{2}$ Demography study site.

${ }^{3}$ This site consists of two historical sites and one new site located within 100 to $220 \mathrm{~m}$ of each other: (1) Ledge W of talus slope; (2) Talus slope, W of Cueva Valdez beach; and (3) Areas immediately surrounding mouth of larger canyon at Cueva Valdez.

${ }^{4}$ This site consists of four new subsites located east of Eagle Canyon: (1) Bluffs above small beaches immediately W of beach at Cañada del Agua, (2) Three patches on bluffs above beach W of Cañada del Agua Canyon mouth, (3) Patch inside canyon walls of mouth of Cañada del Agua, and (4) Patch 50 m E of mouth of Canada del Agua.

${ }^{5}$ National Park Service Botanist and S. McCabe discovered these sites, independent from U.S. Geological Survey work. Adjacent bluffs were not surveyed; likely several to many more plants exist on vertical bluffs below. 


\section{Santa Rosa Island}

A 1941 R. Moran collection (Collection Number 807; Consortium of California Herbaria, 2019) was reported from Santa Rosa Island. However, the U.S. Fish and Wildlife Service (USFWS) recovery plan (2000) indicates that this occurrence was a misidentification, subsequently determined to be Galium nuttallii ssp. insulare.

\section{San Miguel Island}

Figure 5 shows sea-cliff bedstraw localities on San Miguel Island as of 1998, and table 5 shows numbers of plants estimated to be present at each site (Consortium of California Herbaria, 2019). Recent images collected in 2015 (Morgan, Ball and others, Wildlands Conservation Science, unpub. data, 2017, Wildlands Inc.) may indicate increases in occurrence sizes and extents, and possibly new locations, but we have not seen the data. Of interest is a recently "rediscovered" Hoffman collection that seems to have been from plants that were farther inland than where they currently occur. More analysis of San Miguel Island is needed to definitively update the status of sea-cliff bedstraw there.

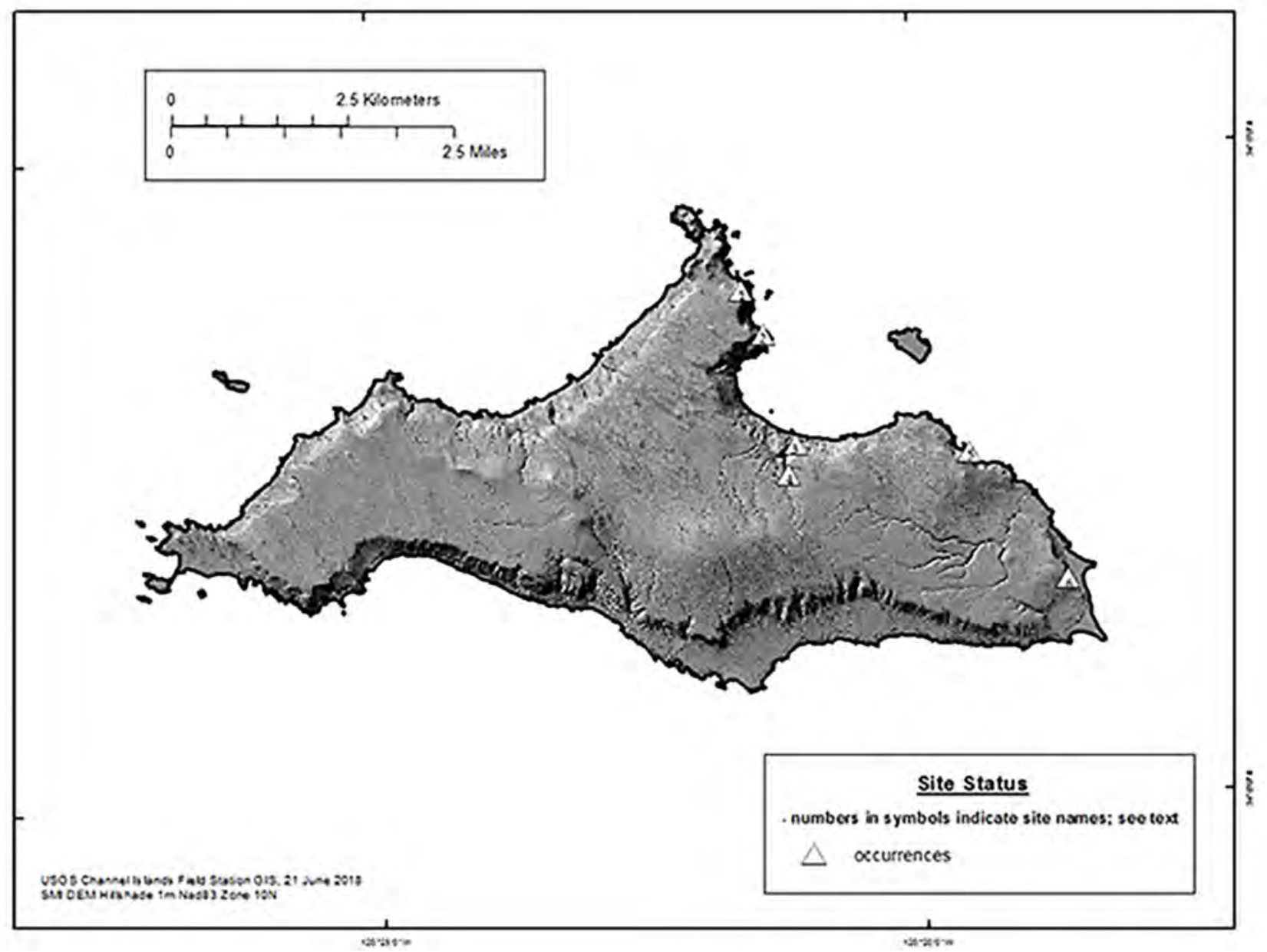

Figure 5. Sea-cliff bedstraw (Galium buxifolium) distribution 1930-98 on San Miguel Island, California. 
Table 5. Numbers of sea-cliff bedstraw (Galium buxifolium) plants estimated from historic records to be present at each site, 18861998, San Miguel Island, California, ordered alphabetically.

\begin{tabular}{cclr}
\hline Site \# & Year & \multicolumn{1}{c}{ Site name } & \# of plants \\
\hline 5 & 1995 & Bat Rock & 200 \\
1 & 1961 & Fish & $>0$ \\
1 & 1963 & Fish & $>0$ \\
1 & 1966 & Fish & $>0$ \\
6 & 1993 & Hare Rock & 200 \\
6 & 1993 & Hare Rock & $150-200$ \\
6 & 1995 & Hare Rock & 250 \\
6 & 1998 & Hare Rock & 300 \\
2 & 1966 & Hoffmann Pt. & $>0$ \\
2 & 1978 & Hoffmann Pt. & 15 \\
3 & 1930 & Nidever Canyon lower & $>0$ \\
3 & 1993 & Nidever Canyon lower & $7-15$ \\
3 & 1995 & Nidever Canyon lower & 1 \\
3 & 1998 & Nidever Canyon lower & 121 \\
3 & 1998 & Nidever Canyon lower & $>0$ \\
4 & 1930 & Nidever Canyon upper & $>0$ \\
na & 1886 & San Miguel Island & $>0$ \\
na & 1930 & San Miguel Island & $>0$ \\
na & 1932 & San Miguel Island & $>0$ \\
na & 1932 & San Miguel Island & $>0$ \\
na & 1932 & San Miguel Island & $>0$ \\
\hline & & &
\end{tabular}

\section{Life History and Population Structure, 2005-06, at Eagle Canyon, Tinker's Cove, and Cueva Valdez, Santa Cruz Island, California}

Our Santa Cruz Island surveys showed that although most of the 27 occurrences that we documented occupied inaccessible, vertical sea-cliff faces (McEachern and others, 2010a), there were a few populations where some of the plants were within reach. We chose four populations for study in 2005-06 to obtain some basic life-history and population-structure information. Objectives were to (1) determine whether a range of plant sizes and reproductive stages was present in each population as evidence of past recruitment and reproductive potential, (2) assess the ratio of floral types present as an indicator of risk of reproductive failure by isolation from other populations, and (3) assess any patterns of mortality evident over a 1-year period. Three study populations were accessible from the beach, including plants growing in native coastal bluff scrub on consolidated rock faces at the mouth of Eagle Canyon and at Tinker's Cove, and on a rock scree slope at Cueva Valdez.

The fourth population, located at Pelican Bay, was unusual because it was the only site where plants were spreading from the cliff face onto the adjacent marine terrace in 2005- a distribution reminiscent of the historic pattern described as “... formerly more common on terraces..." (Hochberg and others, 1979). At that site, the bedstraw grew among retaining walls, paths, and terraces constructed by the nearby Pelican Bay Resort that was active in the early 1900s (Eaton, 1980). However, the site was invaded by greater periwinkle (Vinca major), a non-native sprawling vine planted there in the early 1900s by the Pelican Bay Resort (Eaton, 1980) that covered nearly the entire bedstraw population. In 2007, we developed a study plan (McEachern and Chess, 2007) and obtained an Intra-service biological opinion (U.S. Fish and Wildlife Service, 2007) to conduct periwinkle control using herbicide in 2008 and 2009. Therefore, our 2005-06 monitoring at Pelican Bay became a pre-treatment baseline for continued post-treatment sampling in 2008, 2011, and 2014. We report on our studies of the three beach sites in this section. More details on the Pelican Bay project are given in McEachern and others (2010a) and the next section of this report. 


\section{Methods: Life History and Population Structure at Eagle Canyon, Tinker's Cove, and Cueva Valdez,} 2005-06

At the three beach sites, in 2005, we established a baseline transect along the low-elevation, beach edge of the population and tagged each plant that we could reach with a numbered aluminum tag loosely wired to the stem. For each tagged plant, we recorded its position along the baseline transect and the perpendicular distance from the baseline to the base of the plant. We recorded (1) plant height following along the main stem from ground level to the highest part of the canopy; (2) the longest canopy length and the widest canopy width perpendicular to the length to the nearest centimeter; (3) the diameter of the stem at ground level to the nearest 0.01 centimeter using dial calipers; (4) plant stage (seedling, vegetative, or reproductive plants with buds, flowers, or fruits); and (5) floral type (pistillate, staminate, or perfect/bisexual). We relocated each tagged plant in 2006 and made these same measurements again. Plants that died or disappeared between the 2 years were scored as dead. We counted new seedlings in 2006, but because we did not have a bounded plot, these were not quantitative data based on a thorough search for recruitment in a given area.

\section{Results and Discussion: Life-History and Population Structure at Eagle Canyon, Tinker's Cove, and Cueva Valdez, 2005-06}

We were able to reach and measure between 11 and 40 plants at the beach sites in 2005 and 2006 (table 6); the larger plot at Pelican Bay included slightly more than 100 plants those same years.

Table 6. Numbers of sea-cliff bedstraw (Galium buxifolium) sampled at Eagle Canyon, Tinker's Cove, and Cueva Valdez on Santa Cruz Island, California, 2005-06.

\begin{tabular}{cccc}
\hline \multicolumn{4}{c}{ Numbers of plants sampled at three sites, 2005-06 } \\
\hline & Eagle Canyon & Cueva Valdez & Tinker's Cove \\
\hline 2005 & 37 & 15 & 12 \\
2006 & 40 & 15 & 11 \\
\hline
\end{tabular}

Although it is not possible to assess population trend with only 2 years of data from the three sites, the numbers of plants present across the range of life-history stages from newly germinated seedlings to reproductive adults (fig. 6) provides a snapshot showing whether the population has been recruiting individuals, whether the capacity for regeneration via seed production exists, and whether plants were lost. For example, all three life-history stages that we scored (first-year seedling, prereproductive vegetative plant, and reproductive plants) were present at Eagle Canyon both years. All the plants at Cueva Valdez were reproductive both years, whereas the proportion (table 7) of plants producing fruits at Tinker's Cove increased from 58 to 82 percent between the 2 years.

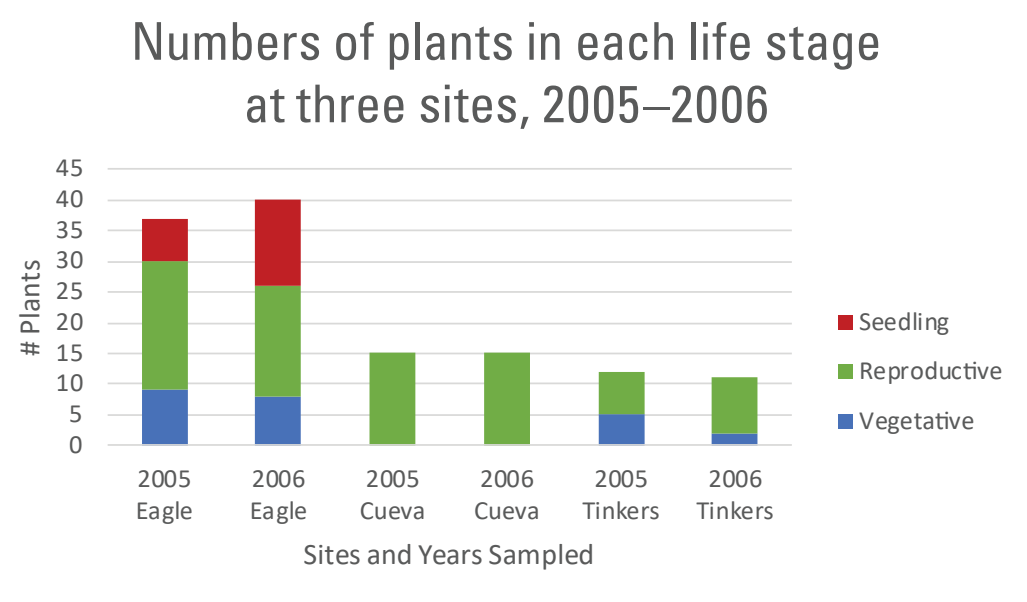

Figure 6. Numbers of sea-cliff bedstraw (Galium buxifolium) plants present across life-history stage in samples at Eagle Canyon, Tinker's Cove, and Cueva Valdez on Santa Cruz Island, California, 2005-06. 
Table 7. Percent of life-history stages present in sea-cliff bedstraw (Galium buxifolium) samples at Eagle Canyon, Tinker's Cove, and Cueva Valdez on Santa Cruz Island, California, 2005-06.

\begin{tabular}{lccrrrr}
\hline & \multicolumn{2}{c}{ Eagle Canyon } & \multicolumn{2}{c}{ Cueva Valdez } & \multicolumn{2}{c}{ Tinker's Cove } \\
& $\mathbf{2 0 0 5}$ & $\mathbf{2 0 0 6}$ & $\mathbf{2 0 0 5}$ & $\mathbf{2 0 0 6}$ & $\mathbf{2 0 0 5}$ & $\mathbf{2 0 0 6}$ \\
\hline Vegetative & 24 & 20 & 0 & 0 & 42 & 18 \\
Reproductive & 57 & 45 & 100 & 100 & 58 & 82 \\
Seedling & 19 & 35 & 0 & 0 & 0 & 0 \\
\hline
\end{tabular}

Plants were lost at both Eagle Canyon and Tinker's Cove between years; there was no mortality of tagged plants at Cueva Valdez. There was no obvious visible change between years in the habitat where these plants were growing. At Eagle Canyon, 10 plants died, including 4 of the 72005 seedlings and the 4 smallest vegetative plants. Two of the moderately large reproductive plants were also lost for reasons that were unclear - there was no evident disturbance where they were growing; they simply disappeared. This loss in numbers was offset, however, by the germination of 14 seedlings, for a net gain in numbers between the 2 years. Because we did not continue monitoring past 2006, it is unclear how long-lasting this offset might be. One small vegetative plant died at Tinker's Cove, and there was no evident recruitment within reach, for a slight loss there.

The sea-cliff bedstraw plants were very difficult to measure consistently from the beach because the plants are difficult to reach. Plant sizes were highly variable by all measures (table 8); standard deviations were high relative to means. Generally, plant height remained the most consistent measure of plant size across the years. Canopy area ranged across several orders of magnitude at Eagle Canyon and Tinker's Cove between years. Basal diameter was impossible to measure accurately without damaging bedstraw plants or their neighbors; we were able to measure about 25 and 80 percent of the basal diameters at the sites in the 2 years. Therefore, plant height may be the best indicator of size in analyses of trends within the beach populations over time.

Overall, the plants within reach at Cueva Valdez tended to be larger than at the other two sites. Seedlings with cotyledons overlapped the smallest vegetative plants in size at Eagle Canyon. There was no consistent tendency for reproductive plants to be larger than vegetative ones at Eagle Canyon or Tinker's Cove, where both life-history stages were represented.

Table 8. Mean plant sizes of sea-cliff bedstraw (Galium buxifolium) plants at Eagle Canyon, Tinker's Cove, and Cueva Valdez on Santa Cruz Island, California, 2005-06.

\begin{tabular}{|c|c|c|c|c|c|c|}
\hline & \multicolumn{2}{|c|}{ Eagle Canyon } & \multicolumn{2}{|c|}{ Cueva Valdez } & \multicolumn{2}{|c|}{ Tinker's Cove } \\
\hline & 2005 & 2006 & 2005 & 2006 & 2005 & 2006 \\
\hline \multicolumn{7}{|c|}{ Plant height $(\mathrm{cm})$} \\
\hline Minimum & 1.0 & 1.0 & 13.5 & 2.0 & 10.0 & 10.0 \\
\hline Maximum & 55.0 & 58.0 & 150.0 & 71.0 & 52.5 & 60.0 \\
\hline Mean & 19.9 & 17.0 & 45.5 & 34.3 & 29.5 & 37.1 \\
\hline Standard deviation & 14.9 & 14.5 & 31.8 & 15.9 & 14.3 & 15.1 \\
\hline \multicolumn{7}{|c|}{ Canopy area $\left(\mathrm{cm}^{2}\right)$} \\
\hline Minimum & 0.5 & 0.0 & 70.0 & 50.0 & 27.0 & 30.0 \\
\hline Maximum & $13,778.0$ & $7,704.0$ & $33,600.0$ & $10,126.0$ & $2,772.0$ & $2,115.0$ \\
\hline Mean & 743.6 & 720.6 & $5,238.2$ & $2,472.0$ & 790.6 & 771.0 \\
\hline Standard deviation & 2,274 & 1,267 & 8,641 & 3,108 & 993 & 721 \\
\hline \multicolumn{7}{|c|}{ Basal diameter $(\mathrm{cm})$} \\
\hline Minimum & 0.6 & 0.4 & 4.7 & 4.2 & 2.0 & 2.1 \\
\hline Maximum & 12.0 & 13.0 & 53.3 & 44.8 & 6.5 & 8.5 \\
\hline Mean & 4.7 & 2.2 & 15.5 & 14.2 & 3.9 & 4.9 \\
\hline Standard deviation & 3.3 & 3.2 & 15.8 & 12.4 & 1.5 & 1.9 \\
\hline
\end{tabular}

Table 9 shows the sample dates at each site in 2005 and 2006. There were some plants flowering at each site in our May and June samples, but plants were past flowering during our July sample date at Tinker's Cove. In general, it was too early to collect fruits during May and June, so we revisited plants in July to collect seeds for seed bank storage (McEachern and others, 2010a). 
Table 9. Sea-cliff bedstraw (Galium buxifolium) sample dates at Eagle Canyon, Tinker's Cove, and Cueva Valdez on Santa Cruz Island, California, 2005-06.

\begin{tabular}{lll}
\hline \multicolumn{1}{c}{ Sample dates at Eagle Canyon, Tinker's Cove, and Cueva Valdez, 2005-06 } \\
\hline Site & \multicolumn{1}{c}{$\mathbf{2 0 0 5}$} & \multicolumn{1}{c}{$\mathbf{2 0 0 6}$} \\
\hline Eagle Canyon & May 13-16 & Jun 9-12 \\
Cueva Valdez & May 17-Jul 6 & Jun 11-Jul 21 \\
Tinker's Cove & May 25 & Jul 17 \\
\hline
\end{tabular}

We used Dempster's $(1973,1993)$ descriptions of floral types to score plants as predominantly pistillate, staminate, or perfect (bisexual). Often the flowers were in a range of stages of maturity on any given plant, a phenomenon seen on herbarium specimens as well. We inspected many flowers on each plant, seeking the most mature ones to determine floral type. Most flowers had both male and female structures, but for many these varied in size relative to one another within the flower. Plants were scored as pistillate if the majority of the most mature flowers had a large pistil and tiny or vestigial stamens. Plants were called staminate if most flowers had large exserted stamens with only a small or vestigial pistil. Plants were scored as perfect when flowers had both pistillate and staminate parts present and they were similar in size and maturity.

Figure 7 shows the percentage of floral types present at the sites in 2005 and 2006. During the May and June sampling we were able to identify floral types on between 33 and 100 percent of the reproductive plants within reach at the beach sites. Otherwise, the flowers were so immature (May/June) or too mature (July) across the majority of the plant that we could not get a clear sense of a predominant flower type. We saw what we identified as perfect flowers on 11 to 37 percent of the plants at Eagle Canyon and Cueva Valdez, none at Tinker's Cove. The ratio of female to male plants was balanced in 2005 at Eagle Canyon and in both years at Tinker's Cove. In 2006 the only flowers we could identify at Eagle Canyon were pistillate. All the plants at Cueva Valdez were reproductive both years. There, the plants with mainly staminate flowers greatly outnumbered pistillate ones in 2005, whereas the opposite pattern was seen in 2006.

Overall, 66 percent of the individuals at Eagle Canyon changed their floral type between years, along with 50 percent at Cueva Valdez. It is not clear from our data what mechanism underlies such apparent inconsistency. It could be that plants switch facultatively from one type to another from year to year in response to some cue, or that the apparent floral type varies with flower maturity or flowering time so that plants would be scored differently at different dates as the flowers develop. This question might be resolved if plants could be visited multiple times during the flowering season. Also unknown from our work in the field is how floral type relates to fruit set and seed viability. We began studies following flower development on nursery plants at the Santa Barbara Botanic Garden in 2005 (Dieter Wilken, Santa Barbara Botanic Garden, unpub. data, 2005), but those plants were lost in a 2009 fire. Interestingly, before they were lost, it looked as if most were turning out to be mainly pistillate (Dieter Wilken, Santa Barbara Botanic Garden, oral commun., 2009). Whether that skewed sex ratio was in response to nursery conditions, or an artifact of non-random seed collection or germination in the production of the nursery plants, remains unknown.

Percent of floral types at three sites, 2005-2006

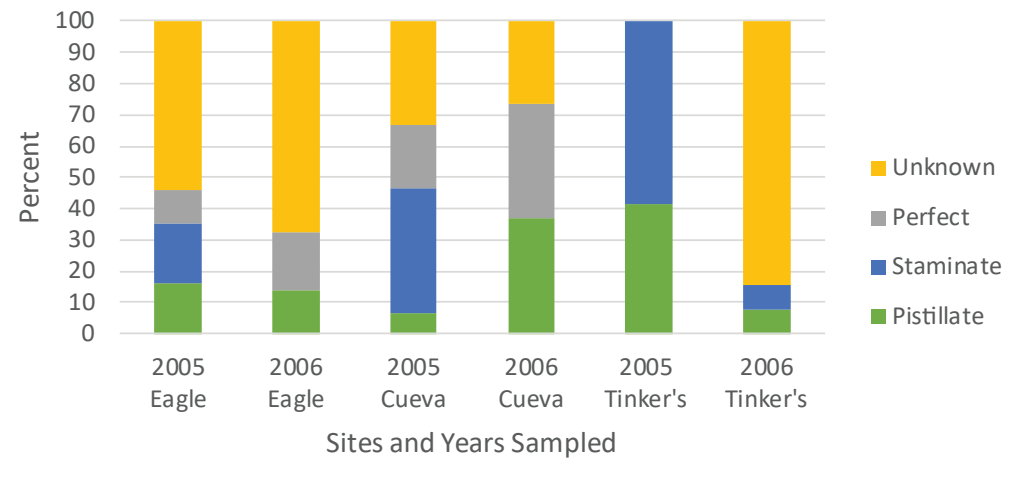

Figure 7. Percent of floral types represented among sea-cliff bedstraw (Galium buxifolium) at Eagle Canyon, Tinker's Cove, and Cueva Valdez on Santa Cruz Island, California, 2005-06. 


\section{Life-History, Population Demography, and Invasive Plant Control at Pelican Bay, 2005-14}

\section{Methods: Pelican Bay Demography and Invasive Plant Control}

At Pelican Bay we established a bounded plot of approximately 930 square meters $\left(\mathrm{m}^{2}\right)$ extending from the cliff edge to several meters past the inland extent of the plants, encompassing all of the accessible plants on the terrace, including about 90 percent of the total population (fig. 8). We sampled this site in 2005 and 2006, and again in 2008, 2010, 2011 , and 2014. Our intent was twofold: (1) to understand population demography by tracking all individuals in the plot over several years for estimates of individual plant growth and longevity, as well as population-level survivorship and recruitment, and (2) to assess the efficacy of periwinkle control and document the effects on sea-cliff bedstraw population trend (McEachern and Chess, 2007). We mapped and tagged each sea-cliff bedstraw plant in the plot and made the same measurements as at the beach sites. In addition, we searched the entire plot for new plants each sample year, identifying them as either seedlings (plants with cotyledons indicating they had germinated that year), or small plants establishing in a prior non-sample year. From 2005 through 2011, we mapped and tagged these new plants, tracking them individually as with the other, older plants in the plot. We stopped tagging new small plants individually after 2011 because we were limited by time and funding constraints, then we switched to simply counting them so that we could still assess overall patterns of recruitment and mortality. However, in 2014 , we continued tracking the 106 plants that were established in the plot (including all plants in all life stages in 2005, plus non-seedling plants in 2006) at the inception of the study in 2005-06, and we recorded mortality, size, reproductive status, and floral morphology as usual for each individual.

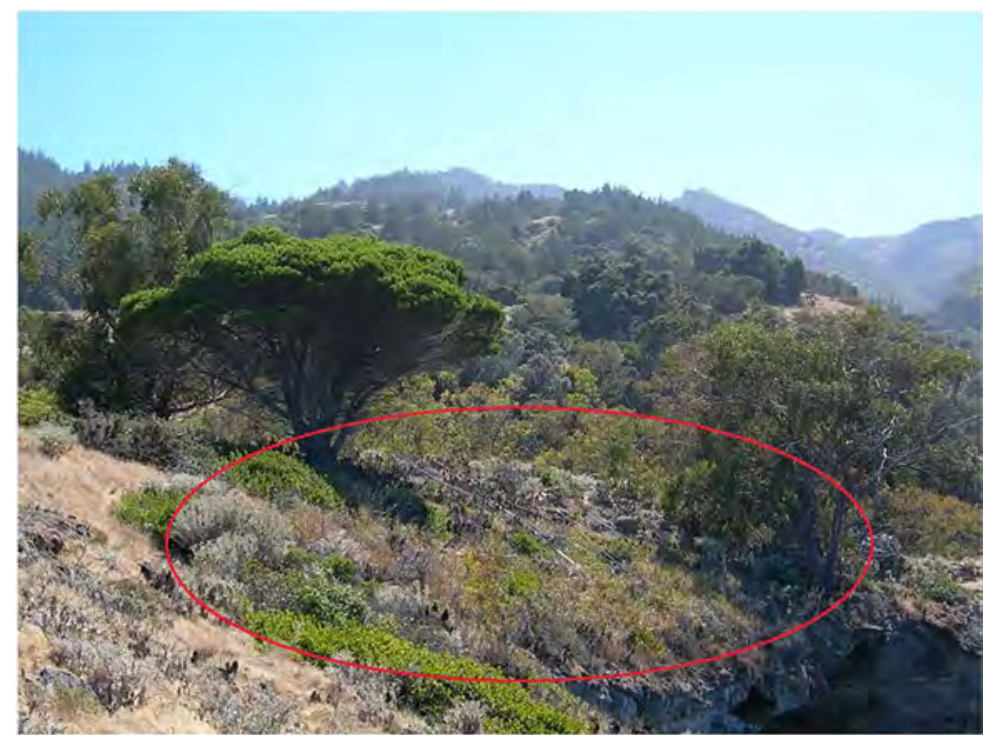

Figure 8. Sea-cliff bedstraw (Galium buxifolium) population at Pelican Bay, 2008. Oval encompasses sea-cliff bedstraw population and study plot. Photo: Katherine Chess, U.S. Geological Survey. 
In 2007, we consulted with USFWS on potential effects of periwinkle treatment with the herbicide glyphosate on the bedstraw population (McEachern and Chess, 2007), resulting in the Intra-service biological opinion that the potential benefits to the endangered plant outweighed any possible negative effects of mortality from carefully applied herbicide (U.S. Fish and Wildlife Service, 2007). Accordingly, we contracted with consultant Channel Islands Restoration to hand-apply herbicide to periwinkle wherever it was accessible in and near the sea-cliff bedstraw population in 2009 and following years as needed (fig. 9). During herbicide application, individual bedstraw plants were disentangled from the periwinkle and covered with plastic sheeting to protect them from overspray. Then, leaves of adjacent periwinkle were wounded lightly with a wire brush, and herbicide was hand-applied using a small brush. The herbicide was allowed to dry for up to several hours, and then the plastic protection was removed from the bedstraw. The applicators moved systematically through the population and treated all the periwinkle within the sea-cliff bedstraw over a period of several days. Herbicide application was repeated in 2010, and any remaining sprouts and new seedlings were hand-pulled in 2010 and 2013 (McEachern and others, 2010b). Prior to herbicide application, we established 20 transects traversing the length of the periwinkle-infested area, and we estimated periwinkle point-line-intercept cover of live periwinkle along each (Bonham, 1989). We inspected the treatment area and visually estimated periwinkle kill rates in April 2009 and May 2010, and we repeated the transect cover sampling in May 2014, for an estimate of long-term control efficacy.

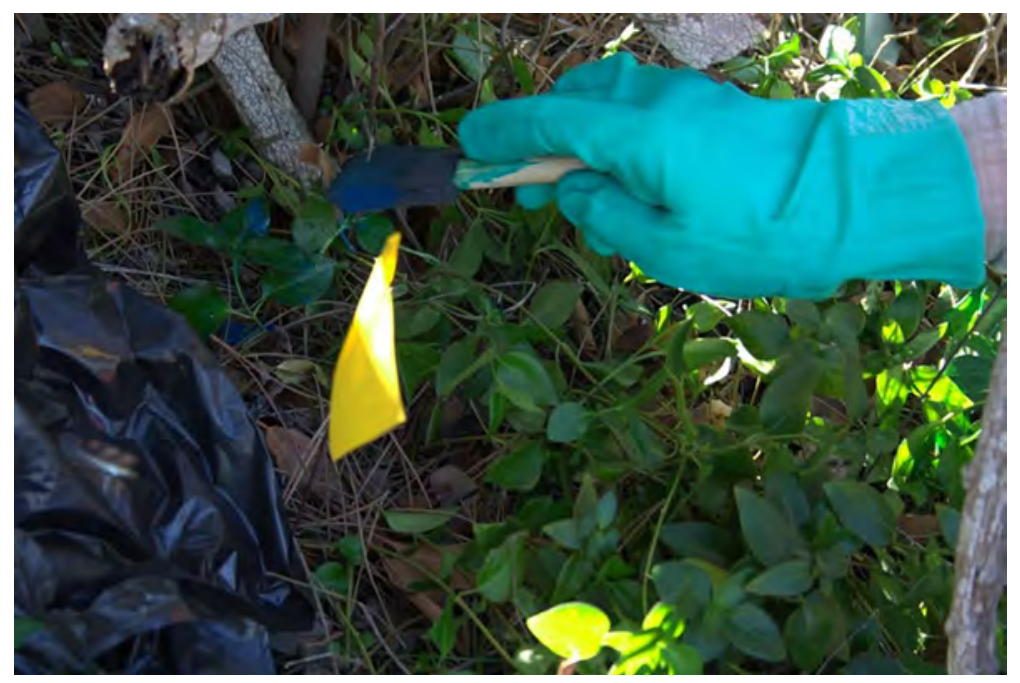

Figure 9. Hand-application of herbicide to greater periwinkle (Vinca major) within a population of sea-cliff bedstraw (Galium buxifolium) at Pelican Bay, Santa Cruz Island, California, 2009. Photo: Ken Owen, Channel Islands Restoration.

The Pelican Bay sea-cliff bedstraw population was growing in the shadow of a large non-native and highly invasive stone pine (Pinus pinea). On January 18-22, 2011, the tree was removed, and great care was taken by removal crews to not harm any sea-cliff bedstraw plants. Thus, our May 2010, 2011, and 2014 demography monitoring allowed us to assess the effects of both periwinkle control and stone pine removal on the sea-cliff bedstraw population.

\section{Results and Discussion: Pelican Bay Demography and Invasive Plant Control}

\section{Sampling and Treatment Timeline}

The Pelican Bay plot was sampled late in the flowering seasons of 2005 and 2006. In each subsequent year, the plot was sampled in May, at about the middle of the flowering period; the best time for assessing floral morphology because young and old flowers were present, along with developing fruits. Also, in May, seedlings were big enough to see and identify easily because they had 1-2 pairs of true leaves and still-green cotyledons. Table 10 shows sample dates and timing of periwinkle control and stone pine removal. Altogether, 837 sea-cliff bedstraw plants were tagged and tracked over the study period. 
Table 10. Sampling and treatment dates at the Pelican Bay sea-cliff bedstraw (Galium buxifolium) population, 2005-14, Santa Cruz Island, California.

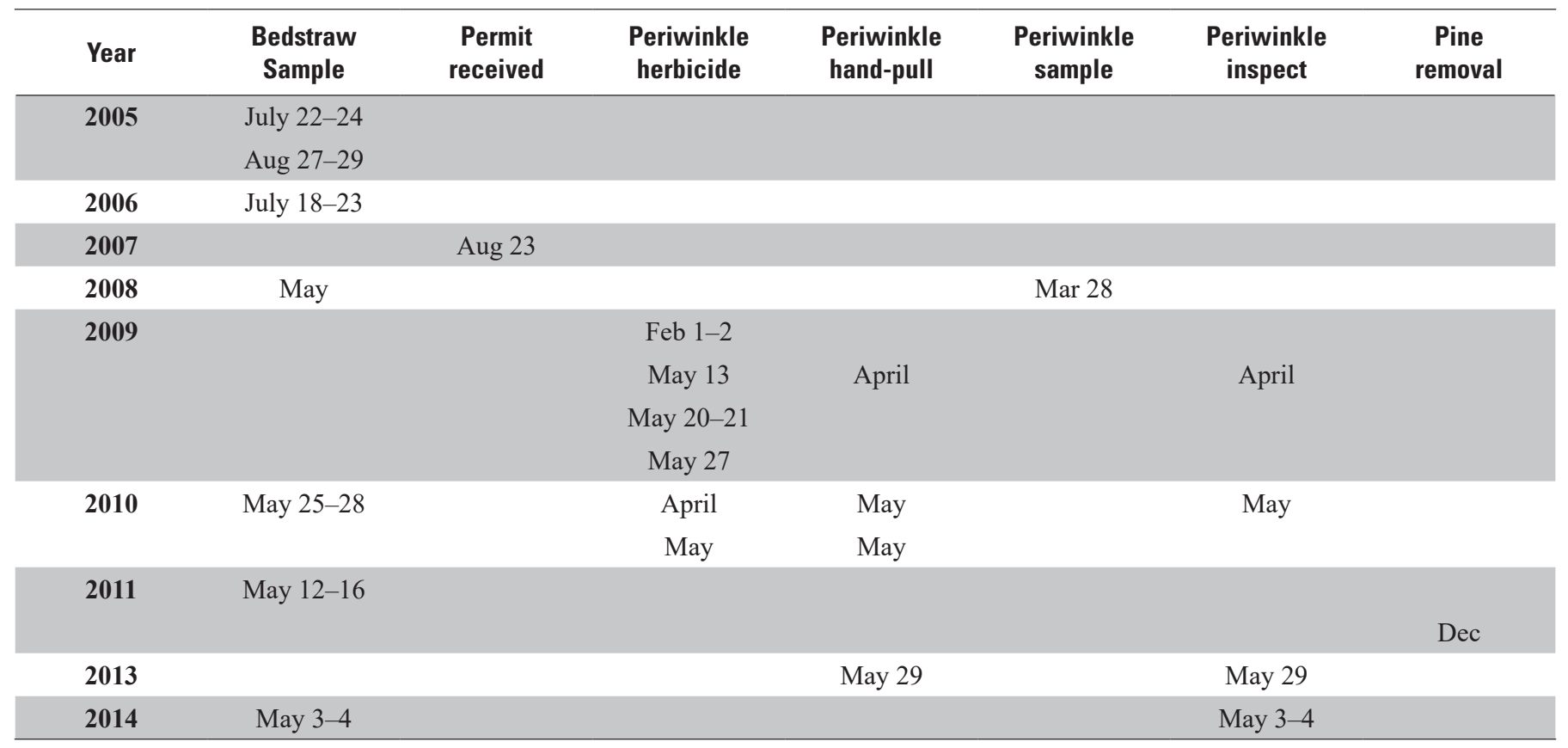

\section{Population Stage Structure, Recruitment, and Mortality, 2005-14}

Numbers of plants alive in the plot (table 11) varied from a pre-treatment low of 105 in 2005 to a high of 639 in 2011, after 2 successive years of periwinkle herbicide application (2008-09) followed by 1 year of hand-pulling. However, numbers of individuals declined by about half between 2011 and 2014. Figure 10 displays the number of plants alive in the plot grouped by stage class. It is clear that the increase after 2008 was driven by a flush of recruitment of new plants from seed in 2010, contributing to large numbers of plants the following 4 years.

Table 11. Total live plants present in the Pelican Bay sea-cliff bedstraw (Galium buxifolium) plot, 2005-14, Santa Cruz Island, California.

\begin{tabular}{ccccccc}
\hline & $\mathbf{2 0 0 5}$ & $\mathbf{2 0 0 6}$ & $\mathbf{2 0 0 8}$ & $\mathbf{2 0 1 0}$ & $\mathbf{2 0 1 1}$ & $\mathbf{2 0 1 4}$ \\
\hline Total live plants & 106 & 123 & 131 & 507 & 639 & 341 \\
\hline
\end{tabular}




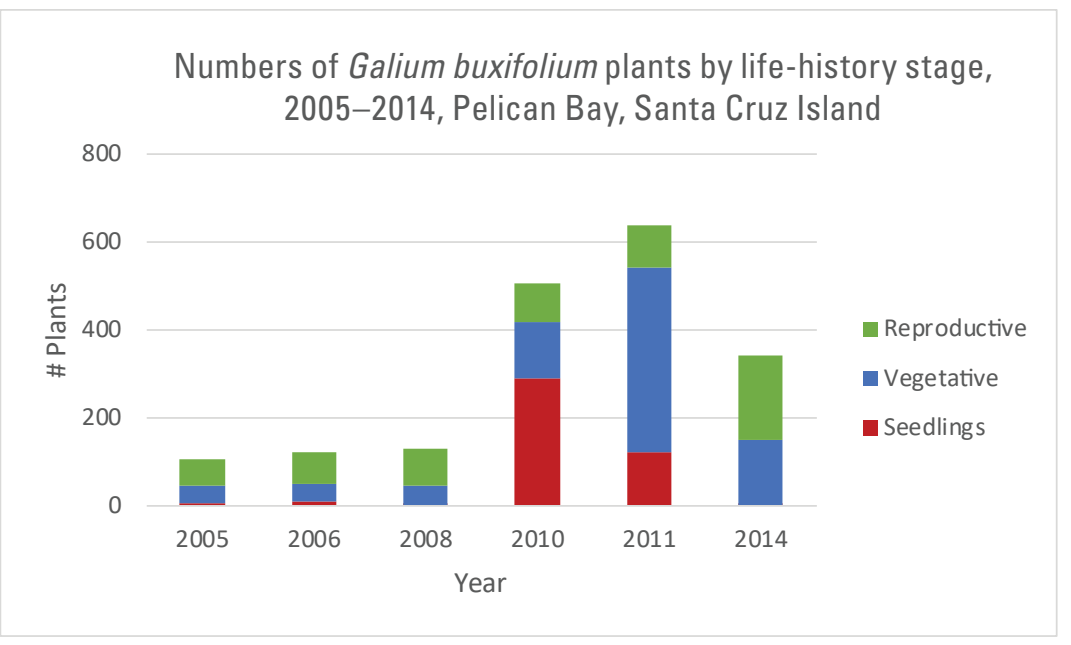

Figure 10. Numbers of sea-cliff bedstraw (Galium buxifolium) across life-history stages at Pelican Bay on Santa Cruz Island, California, 2005-14.

The proportion of seedlings in the population varied widely, from 1 percent in 2008 and 2014 to 57 percent in 2010. Essentially, prior to 2010, the population consisted mainly of older established vegetative and reproductive plants with little annual recruitment; in 2010, the population flipped to about half seedlings and half established plants. That pattern changed back to a population dominated by established plants by 2014. About half of the 2010 seedlings did not re-sprout after the summer drought-dormant season (fig. 10). However, recruitment and survival of many 2010 and 2011 seedlings resulted in a 2014 population about three times larger than in 2005-08. Thus, population dynamics, at least over the short term of our study, were driven by episodic recruitment rather than by mortality.

\section{Fates of the Original 106 Vegetative and Reproductive Plants Found in 2005-06}

In 2014, we found and measured only the original non-seedling plants tagged in 2005-06. In 2005, we found 96 plants that were not seedlings, that is, lacking cotyledons and in the vegetative and reproductive life stages; in 2006, we found an additional 10 such plants for a total of 106 "original" plants. Tracking their fates gives us a more nuanced view of patterns of fecundity and mortality among established plants in the Pelican Bay population pre- and post-treatment. Overall, only 16 (6.6 percent) of these plants died over the study period (fig. 11). Plants vacillated between being vegetative or reproductive over the years; 4.7 percent remained vegetative across all years, 43.4 percent remained reproductive all years, and 51.9 percent switched between vegetative and reproductive states. Despite these differences, however, more than half of these original, established plants were reproductive each year. As a result, seed output in the population does not seem constrained by failure of older plants to reproduce. 


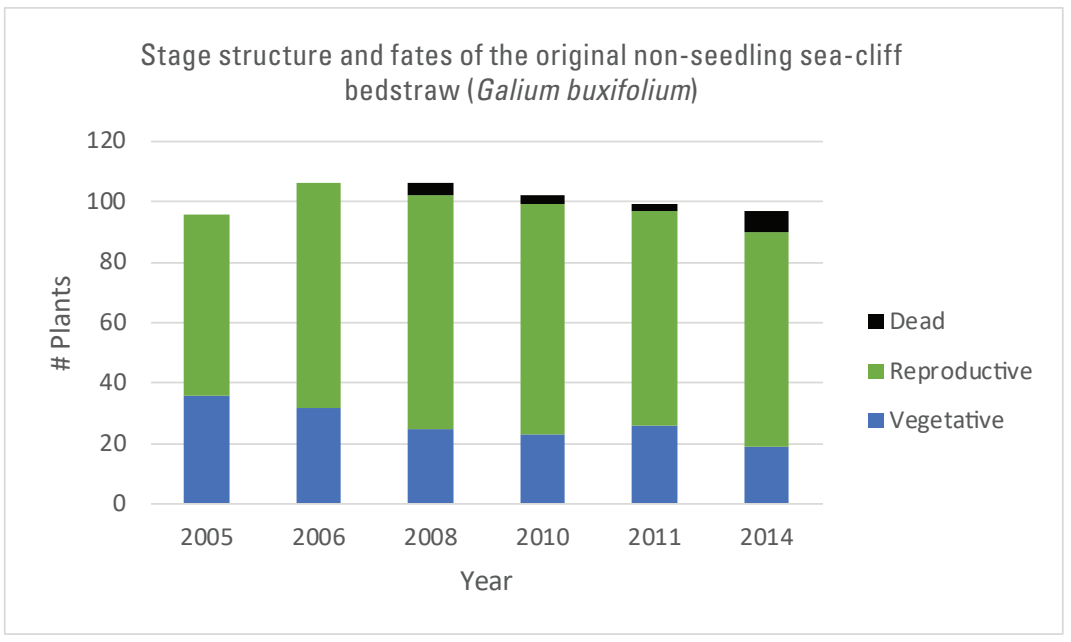

Figure 11. Stage structure and fates of the original non-seedling sea-cliff bedstraw (Galium buxifolium) plants tagged in 2005 ( $\mathrm{n}=96$ ) and 2006 ( $n=106$ ) in the Pelican Bay plot on Santa Cruz Island, California, tracked individually 2005-14.

\section{Plant Size}

There was a wide range of plant sizes among the vegetative and reproductive plants at Pelican Bay by all estimates (table 12), as would be expected from a population with plants representing a diverse range of ages. As at the beach sites, basal stem diameter was difficult to measure consistently, even at Pelican Bay where the plants are relatively easy to reach, and that measure was abandoned at Pelican Bay from 2010 onwards.

There was no apparent effect of the periwinkle treatment on plant size following the 2008 and 2009 herbicide treatments, a testament to the careful hand-application methods used to deploy the herbicide. Mean plant size was not highly variable until 2011, when mean plant height and canopy area were nearly half of previous years' measurements. There could be two possible reasons behind this observation. The stone pine was removed in December prior to the May 2011 sample, and greater exposure to desiccation could suppress plant growth. However, there was no appreciable increase in established plant mortality (fig. 11) in 2011; most of the change in plant numbers was driven by seedling mortality. It is more likely that the decrease in mean size shows the effect of recruitment of all 152 of the surviving 2010 seedlings into the vegetative stage of the population; the remaining 137 died, none were reproductive the year following germination. The increased mean sizes in 2014 reflect the fact that only the older plants that were already in the mature population in 2005 and 2006 were sampled ( $\mathrm{n}=90$ surviving individuals). Overall, mean plant heights are most like those at Eagle Canyon, whereas mean canopy area was slightly higher than at Eagle Canyon but much lower than at Tinker's Cove and Cueva Valdez. Both Tinker's Cove and Cueva Valdez had higher proportions of vegetative and reproductive plants with no seedlings. This fact and the larger mean sizes may indicate that those two populations have not recruited new individuals from seed recently in the areas that we could reach near the beach, and so those populations may consist mainly of mature older individuals. 
Table 12. Mean plant size of vegetative and reproductive sea-cliff bedstraw (Galium buxifolium) sampled at Pelican Bay on Santa Cruz Island, California, 2005-14.

[cm, centimeters; $\mathrm{cm}^{2}$, square centimeters; mm, millimeters]

\begin{tabular}{|c|c|c|c|c|c|c|}
\hline Plant height (cm) & 2005 & 2006 & 2008 & 2010 & 2011 & $2014^{1}$ \\
\hline Minimum & 1.5 & 1.0 & 0.3 & 1.0 & 0.5 & 2.0 \\
\hline Maximum & 89.0 & 101.0 & 98.0 & 82.0 & 81.0 & 96.0 \\
\hline Mean & 19.8 & 19.6 & 19.2 & 15.0 & 8.3 & 31.1 \\
\hline Standard deviation & 15.7 & 17.6 & 16.5 & 15.4 & 12.4 & 18.2 \\
\hline Count & 98 & 111 & 131 & 213 & 516 & 90 \\
\hline \multicolumn{7}{|c|}{ Canopy area $\left(\mathrm{cm}^{2}\right)$} \\
\hline Minimum & 0.5 & 0.3 & 0.3 & 0.3 & 0.3 & 0.3 \\
\hline Maximum & 21,672 & 17,825 & 31,488 & 25,026 & 30,758 & 27,200 \\
\hline Mean & 1,034 & 1,043 & 1,304 & 1,005 & 508 & 3,223 \\
\hline Standard deviation & 2,931 & 2,973 & 3,836 & 2,977 & 2,285 & 5,110 \\
\hline Count & 98 & 111 & 128 & 212 & 516 & 80 \\
\hline \multicolumn{7}{|c|}{ Basal diameter $(\mathrm{mm})$} \\
\hline Minimum & 0.5 & 0.5 & 0.5 & na & na & na \\
\hline Maximum & 12.4 & 12.3 & 13.8 & na & na & na \\
\hline Mean & 3.6 & 3.5 & 4.5 & na & na & na \\
\hline Standard deviation & 2.6 & 2.9 & 3.0 & na & na & na \\
\hline Count & 30 & 58 & 46 & na & na & na \\
\hline
\end{tabular}

12014 samples included only the vegetative and reproductive plants established in the plot in 2005 and 2006.

\section{Floral Morphology}

As at the beach sites, plants were scored as pistillate if the majority of the most mature flowers had a large pistil and tiny or vestigial stamens. Plants were called staminate if most flowers had large exserted stamens with only a small or vestigial pistil. Plants were scored as perfect when flowers had both pistillate and staminate parts present and they were similar in size and maturity. We were able to estimate floral morphological type on 13 (in 2005) and 81 (in 2011) plants in the Pelican Bay samples, excluding the year 2006 when the plants were mostly past peak flowering. There was great variety among the plants in flower type, both within one individual and across individuals (table 13). The proportion of plants representing any one type changed by year, perhaps in response to biology, flower age, sample date, or our ability to discern floral morphology correctly; it was likely some combination of all these factors. About 37 percent of the plants we were able to assess changed floral types at least once during the study period, some more than once. As Dempster (1973) described, there was a range of morphologies found in the population. Some individual plants were wholly pistillate, staminate, or perfect, whereas others had flowers with a mix of perfect, pistillate, and staminate morphology. Our observations indicate that flower morphology may change as the flower ages; some plants had young flowers that appeared staminate and other older flowers that were tending toward a more pistillate morphology. Such protandry was not noted by Dempster, perhaps because she was working from herbarium specimens in which it would be difficult to detect such a progression. As at the beach sites, tracking of individual plants over a growing season would be needed to disentangle effects of timing and flower maturity on floral morphology. There were no years in which the Pelican Bay population appeared particularly skewed toward any one morphological type, so if there were a difference in fruit set among types, this would not have been a conservation concern during the sample period. 
Table 13. Percent of floral types represented among reproductive sea-cliff bedstraw (Galium buxifolium) individuals at Pelican Bay, Santa Cruz Island, California, 2005-14.

\begin{tabular}{lcccccc}
\hline & $\begin{array}{c}\mathbf{2 0 0 5} \\
(\mathbf{n}=\mathbf{1 3})\end{array}$ & $\begin{array}{c}\mathbf{2 0 0 6} \\
(\mathbf{n}=\mathbf{0})\end{array}$ & $\begin{array}{c}\mathbf{2 0 0 8} \\
(\mathbf{n}=\mathbf{7 0})\end{array}$ & $\begin{array}{c}\mathbf{2 0 1 0} \\
(\mathbf{n}=\mathbf{4 5})\end{array}$ & $\begin{array}{c}\mathbf{2 0 1 1} \\
(\mathbf{n}=\mathbf{8 1})\end{array}$ & $\begin{array}{c}\mathbf{2 0 1 4} \\
(\mathbf{n}=\mathbf{5 3})\end{array}$ \\
\hline Pistillate & 31 & na & 39 & 40 & 35 & 42 \\
Staminate & 46 & na & 57 & 38 & 27 & 57 \\
Perfect & 23 & na & 0 & 9 & 22 & 2 \\
Pistillate and perfect & 0 & na & 0 & 2 & 7 & 0 \\
Staminate and perfect & 0 & na & 4 & 9 & 9 & 0 \\
Pistillate and staminate and perfect & 0 & na & 0 & 2 & 0 & 0 \\
\hline
\end{tabular}

\section{Fruiting and Flower Morphology}

To better understand the relationship of floral type to fruit set, in 2014, we recorded fruiting along with floral morphology for the 41 reproductive plants that were developing fruits (table 14). We were unable to discern floral type in 17 of the plants because they had progressed beyond flowering and were well into fruit set. Of the remaining 24 plants, about half were scored as pistillate and the other half as staminate. Therefore, at least from this small sample, there does not appear to be a relationship of floral type to fruit production. Next steps would be to follow fruits to maturity and test viability and germination rates, for an estimate of the effect on fecundity.

Table 14. Flower morphology recorded in 2014 for 41 sea-cliff bedstraw (Galium buxifolium) plants that were developing fruits at Pelican Bay, Santa Cruz Island, California.

\begin{tabular}{lc}
\hline \multicolumn{1}{c}{ Flower morphology in $\mathbf{2 0 1 4}$ for $\mathbf{4 1}$ fruiting plants } \\
\hline Pistillate & 12 \\
Staminate & 11 \\
Perfect & 1 \\
Unable to score & 17 \\
\hline
\end{tabular}

\section{Greater Periwinkle (Vinca major) Cover}

Greater periwinkle was sampled by the point-line-intercept transect method (Bonham 1989) in March 2008 and March 2014, for a measure of before- and after-treatment cover. Additionally, the treatment area was walked and inspected to estimate total kill rate in April 2009, May 2010, and May 2013. Visual estimates indicated that about 95 percent of the periwinkle was dead; any seedlings or resprouts seen were hand-pulled at that time. Cover of living periwinkle leaves sampled on transects before treatment in May 2008 totaled 10.4 percent and in May 2014 it was 0.5 percent. The site has not been formally inspected or sampled for live periwinkle cover since 2014, but recent observation by land managers (J. Knapp, The Nature Conservancy, oral commun., 2018) indicates that cover may be increasing and in need of re-treatment. 


\section{Conclusions}

Sea-cliff bedstraw research from 2005 to 2014, accomplished with funding from the National Park Service Biological Inventories and Natural Resource Protection Programs, U.S. Geological Survey, and National Science Foundation (RUI 0950106), included surveys to relocate historic collection sites on Santa Cruz Island and preparation of maps of historic sites from our database on San Miguel Island for future survey. In general, the historically known Santa Cruz Island sites were still extant, mainly inhabiting the sea-cliff face (McEachern and others, 2010a), but not widespread on the adjacent marine terraces as had been described in the past (Hochberg and others, 1979). We noted more known historic occurrences than reported in the listing and recovery plan documents (U.S. Fish and Wildlife Service, 1997, 2000), although this difference may reflect different methods of bounding and counting populations between historic searches and our 2005-06 surveys. It is not possible to estimate whether these population occurrences had shrunk or expanded since collected because the historic herbarium label information was not detailed enough to assess population extent. In addition, we located 14 new occurrences, which doubled the known number of sites occupied by the bedstraw on Santa Cruz Island. The bulk of our sea-cliff bedstraw life-history and demography research was conducted at four sites: three populations accessible from the beach at Eagle Canyon, Tinker's Cove, and Cueva Valdez and one marine terrace site at Pelican Bay.

The literature on floral morphology (Dempster, 1973) indicated a wide range of floral types in the species. This could possibly lead to poor population-level fruit set if floral types were heavily skewed toward predominately pistillate or predominately staminate individuals in these highly isolated populations. However, floral morphology seems generally evenly balanced between mainly pistillate and staminate plants, with other floral types present as well, in the populations we sampled. Furthermore, seed germination trials showed about a 40 percent germination rate from fresh imbibed seeds (Dieter Wilken, Santa Barbara Botanic Garden, unpub. data, 2006), with time to hypocotyl emergence ranging from 4 to more than 10 weeks. Mean seed mass ranged over several orders of magnitude in samples from three study sites, but there was no great difference between individuals with mainly male or mainly female flowers in rates of seed set or seed mass in a small sample from three study populations. Thus, factors such as individual biology or seed mass may play a greater role in seed germination rates and lag times than floral morphology. Importantly, habitat quality may play a role in seed germination: if seeds are allowed to dry out during this protracted germination period, they may fail (Nancy Vivrette, Ransom Seed Lab, oral commun., 2006).

Life-history stage structure varied from purely reproductive plants at Cueva Valdez, to nearly equal representation of vegetative and reproductive plants at Tinker's Cove, to sites with seedlings also present at Eagle Canyon and Pelican Bay. The longer 10-year term of study at Pelican Bay revealed an episodic pattern of high recruitment and relatively lower mortality once plants became established beyond the first summer dormant season, with a cumulative effect over 4 years of increased population size. This flush of seedlings was seen after periwinkle reduction at Pelican Bay, indicating that the periwinkle may have been in part repressing seedling establishment. Other germination cues may be at play, also, because new seedlings did not continue to appear at the same rates over the next few years following periwinkle control.

There were no seedlings observed at Cueva Valdez or Tinker's Cove in 2005 or 2006, although reproductive plants were present both years. There are no prior surveys for seedlings at these two sites that we know of, so it remains unknown whether a paucity of seedlings is a chronic recurring phenomenon there. The fact that these two populations had a range of plant sizes implies that recruitment has occurred at least sporadically in the past. It could be that the short 2-year snapshot at the beach sites captured only part of a similar longer trend in population fluctuation related to germination and recruitment.

It is unclear what effect, if any, the stone pine removal had on Pelican Bay population fluctuation - certainly no plants were directly harmed during tree removal, and the downturn in overall canopy area is attributable to the flush of recruitment of small plants into the population, which brought the mean plant size downward. Mortality was low among the Pelican Bay plants once they survived their first year - mortality was highest among plants transitioning from seedlings to the vegetative stage. About 93 percent of the already-established plants tagged in 2005 and 2006 were still present 10 years later in 2014. Apparently, seacliff bedstraw individuals are long-lived and once established have good survival rates. Taken together, these results imply that population growth is driven more by germination and recruitment into the mature population than by mortality of established plants, at least since feral animal eradication from Santa Cruz Island. Therefore, conservation actions might be best focused on nurturing safe sites for seed germination and seedling survival. Certainly, sea-cliff bedstraw shows the capacity to produce viable seeds and recruit new plants into at least the Pelican Bay population. Comparison of recent surveys (M. Ball and others, unpub. data, 2015) with those made in 2005-07 (McEachern and others, 2010a) may show whether there is a trend toward expansion of those historic sites on Santa Cruz Island. 


\section{References Cited}

Bonham, C., 1989, Measurements for Terrestrial Vegetation: Hoboken, N.J., John Wiley and Sons, 338 p.

Consortium of California Herbaria, 2019, CCH1: Featuring California vascular plant data from the Consortium of California Herbaria and other sources: University of California, Berkeley, database, accessed on March 2, 2019, at http://ucjeps.berkeley.edu/consortium/.

Dempster, L.T., 1973, The polygamous species of the genus Galium (Rubiaceae) section Laphogalium of México and southwestern United States: University California Publications in Botany, v. 64, p. 1-36.

Dempster, L.T., 1993, Rubiaceae, in Hickman, J., ed., The Jepson manual—Higher plants of California: Berkeley, University of California Press, p. 976-986.

Eaton, M.H., 1980, Diary of a sea captain's wife-Tales of Santa Cruz Island: Santa Barbara, Calif., McNally and Loftin West, $256 \mathrm{p}$.

Greene, E.L., 1886, Studies in the botany of California and parts adjacent: Bulletin of the California Academy of Sciences, v. 2, no. 6, p. 150.

Hochberg, M.C., Junak, S.A., Philbrick, R.N., and Timbrook, S., 1979, Botany, of Power, D.M., ed., Natural resources study of the Channel Islands National Monument, California: Santa Barbara, Calif., Santa Barbara Museum of Natural History, p. 5.1-5.85.

Junak, S., Ayers, T., Scott, R., Wilken, D., and Young, D., 1995, A flora of Santa Cruz Island: Santa Barbara, Calif., California Native Plant Society, $408 \mathrm{p}$.

McEachern, K., and Chess, K., 2007, Invasive pest plant eradication from a population of the endangered endemic plant Galium buxifolium on Santa Cruz Island, Channel Islands National Park, California - Study Plan for USFWS Biological OpinionReport to Channel Islands National Park: Ventura, Calif., U.S. Geological Survey, 16 p.

McEachern, A.K., Chess, K.A., and Niessen, K.G., 2010a, Field surveys of rare plants on Santa Cruz Island, California, 20032006-Historical records and current distributions: U.S. Geological Survey Scientific Investigations Report 2009-5264, 34 p., https://doi.org/10.3133/sir20095264.

McEachern, K., Chess, K., Flagg, K., Niessen, K., Owen, K., Thompson, K., and Chang, D., 2010b, Herbicide treatment of invasive Vinca major growing with endangered Galium buxifolium, an island endemic-Proceedings of the California Invasive Plant Council Symposium, 14:1: Berkeley, Calif., California Invasive Plant Council, accessed at https://www.cal-ipc.org.

McEachern, A.K., and Wilken, D.H., 2011, Nine endangered taxa and one recovering ecosystem-Identifying common ground for recovery on Santa Cruz Island, California, in Proceedings of the California Native Plant Society Conservation Conference, January 17-19, 2009: Washington, D.C., California Native Plant Society, p. 162-167.

McEachern, K., Atwater, T., Collins, P.W., Faulkner, K., and Richards, D.V., 2016, Managed island ecosystems, in Mooney, H., and Zavaleta, E., eds., Ecosystems of California: Berkeley, Calif., University of California Press, p. 755-778.

McEachern, A.K., Chess, K.A., Flagg, K., and Niessen, K.G., 2019, Demographic data and location information for the endangered Galium buxifolium from 2005 to 2014 on Santa Cruz and San Miguel Islands, California: U.S. Geological Survey data release, https://doi.org/10.5066/P94J36GC.

Morrison, S., 2007, Reducing risk and enhancing efficiency in non-native vertebrate removal efforts on islands—A 25 year multi-taxa retrospective from Santa Cruz Island, California, in Witmer, G.W., Pitt, W.C., and Fagerstone, K.A., eds., Managing vertebrate invasive species-Proceedings of an International Symposium: Fort Collins, Colo. U. S. Department of Agriculture, Animal and Plant Health Inspection Services, Wildlife Services, National Wildlife Research Center, p. 398-409.

Schumann, K., 1897, Rubiaceae, in Engler, A., and Prantl, K., eds., Die Natürlichen Pflanzenfamilien: Leipzig, Germany, Verlag von Wilhelm Engelmann, v. 4, no. 4, p. 1-156.

Soza, V.L., and Olmstead, R.G., 2010, Evolution of breeding systems and fruits in New World Galium and relatives (Rubiaceae): American Journal of Botany, v. 97, no. 10, p. 1630-1646, https://doi.org/10.3732/ajb.1000130. 
Soza, V., 2012, Galium buxifolium, in Jepson Flora Project (eds.): Jepson eFlora: The Jepson Herbarium, Berkeley, Calif., accessed March 3, 2019, at http://ucjeps.berkeley.edu/eflora/eflora_display.php?tid=26322.

Tibor, D.P., ed., 2001, Inventory of rare and endangered plants of California (6th ed.): Sacramento, Calif., California Native Plant Society, 388 p.

U.S. Fish and Wildlife Service, 1997, Final rule for 13 plant taxa from the northern Channel Islands, California: Washington, D.C., U.S. Fish and Wildlife Service: Federal Register, v. 62, no. 147, p. 40954-40974.

U.S. Fish and Wildlife Service, 2000, Thirteen plant taxa from the Northern Channel Islands Recovery Plan: Portland, Oreg., U.S. Fish and Wildlife Service, 94 p.

U.S. Fish and Wildlife Service, 2007, Intra-service biological opinion on the U.S. Fish and Wildlife Service grant to the County of Santa Barbara Agricultural Commissioner's office for weed control and eradication on Santa Cruz Island, Santa Barbara County, California (1-8-07-FW-58). Letter from Chief, Endangered Species, California/Nevada Operations, Sacramento, California, to Acting Assistant Field Supervisor, August 23, 2007: Ventura, Calif., U.S. Fish and Wildlife Service, Ventura Fish and Wildlife Office, $9 \mathrm{p}$.

U.S. Fish and Wildlife Service, 2009, Galium buxifolium (island bedstraw) 5-Year Review-Summary and evaluation: Ventura, Calif., U.S. Fish and Wildlife Service, Ventura Fish and Wildlife Office, 20 p. 
This page intentionally left blank 
For more information concerning the research in this report, contact the Director, Western Ecological Research Center

U.S. Geological Survey

3020 State University Drive East

Sacramento, California 95819

https://www.usgs.gov/centers/werc 


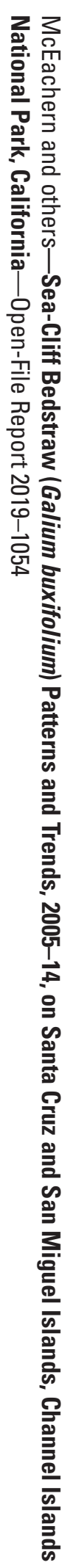

